Historic, Archive Document

Do not assume content reflects current scientific knowledge, policies, or practices. 



\section{Annual Catalogue and Price List}

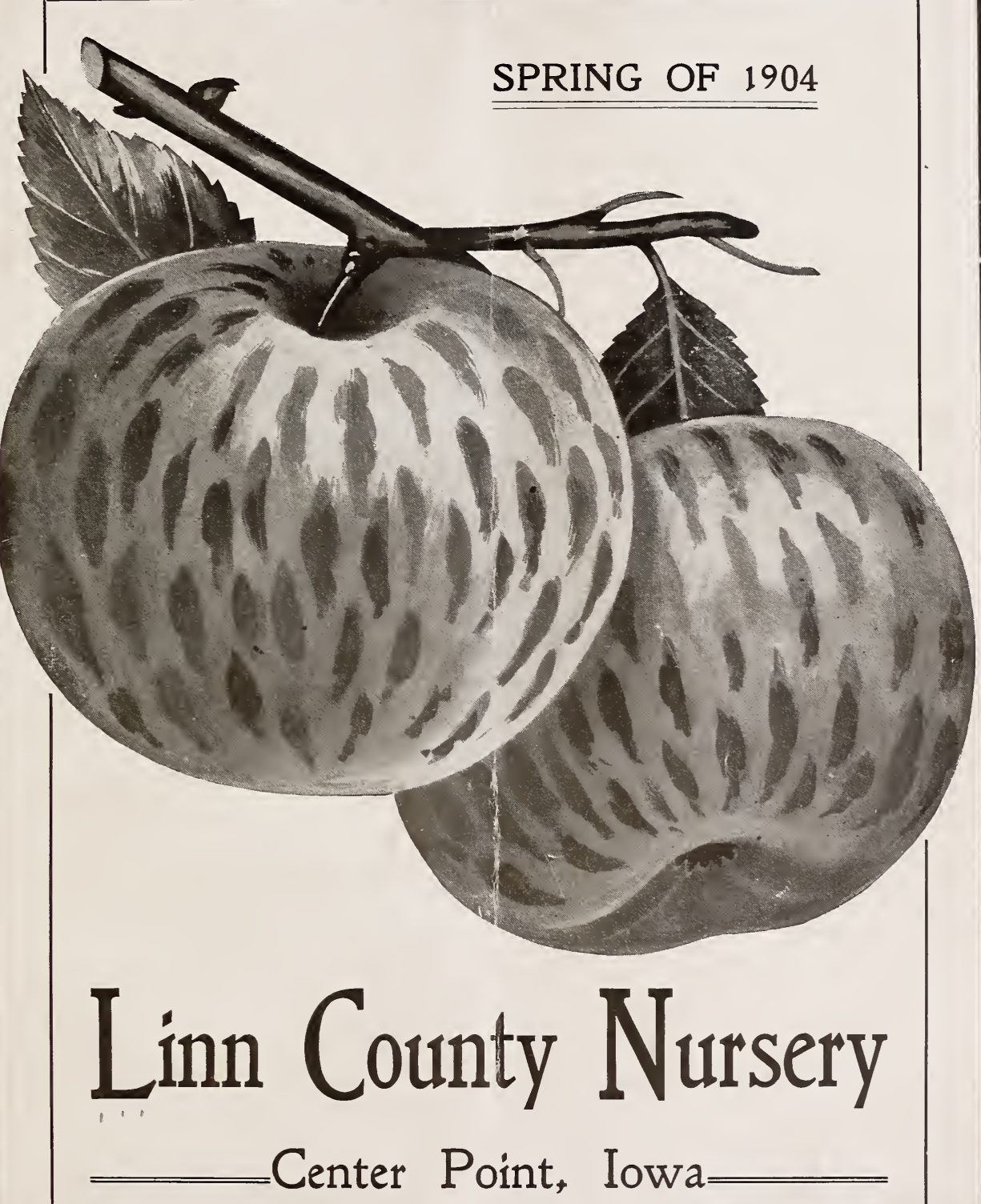

EXPRESS, TELEGRAPH and MONEY ORDER OFFICE: CENTER POINT.

S. W. SNYDER, Successor to A. Snyder \& Son, PROPRIETOR 


\section{STATE OF IOWA. \\ Certificate of Nursery Inspection.}

This is to Certify: That the growing nursery stock and premises of the Linn County Nursery, S. W. Snyder, proprietor, situated in Center Point, County of Linn, State of Iowa, have been inspected according to the provisions of Chapter 53 of the Acts of the Twenty-Seventh General Assembly, and that no indications have been found of the presence of the San Jose Scale or other dangerous insect or plant disease.

This certificate is invalid after June 1, '04. Certificate No. 104.

Dated, September 12, 1903, Ames, Iowa.

H. E. SUMMERS,

State Entomologist. 


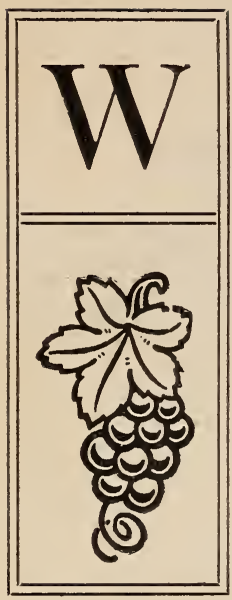

\section{BY WAY OF INTRODUCTION.}

$\mathrm{E}$ take pleasure in submitting herewith our descriptive cata logue and retail price list for spring of 1904 . We are grateful for the liberal patronage which we have enjoyed in the past, and return sincere thanks to our numerous customers, and we hope, with increased facilities and a complete line of stock of our own growing to merit a continuance of the same. To those who have never dealt with us we extend a cordial invitation to get in line and let us try to help you on the way to produce the best fruit in the world-viz., IOWA GROWN.

Twelve years ago we commenced the growing of nursery stock on less than one acre of ground here in Linn county, By honest dealing and an earnest endeavor to please our customers we have been able to increase our planting year by year until now we have 25 acres planted to trees, vines and plants for our increasing trade. While we have been building up our nurseries we have also been planting experimental orchards consisting in importance as in order named: Plum, Apple, Cherry, Peach and Pear, with various plantations of small fruits of which we grow large quantites for market. Of those intending to purchase nursery stock we ask to make a careful examination of our descriptive list. It is based on practical experience and describes our stock truthfully without confusing the buyer in announcing every variety as the best, offering only varieties that ew know to be of value. If recuested we will gladly help you to select varieties suited to your locality, or aid you in any way with our experience in growing fruit for market. We have no secrets. Write us at any time.

Our Method of Fropagation.-In apple grafts we use a four inch root and a six inch scion, using as long a scion as possible and then plant it in the ground up to the top bud in order to get the tree when grown principally upon its own roots, and the first season's growth is cut back to the ground which insures a strong, upright growth-the second year making a straight smooth stem for our tree. Our plum trees are propagated both by grafting and budding upon seedlings produced from seed grown in our own orchard. Cherry and pear are budded on French stocks, the only satisfactory and suitable stock in this line obtainable. Our peach trees are budded upon seedlings grown from native seed of the hardiest known variety (viz., Bailey). which has stood the test for more than 50 years in southeast Iowa.

Improvement by Selection.-We follow the old rule "like produces like," so endeavor to cut every bud and scion we use in propagating from young, vigorous. healthy trees that bear good annual crops of fine fruit. Careful experience has taught farmers that they must plant the bes seed, if a profitable crop is expected. If propagating wood is cut from sickly and unfruitful trees we must expect to grow trees like their parents. In every orchard there are trees of the same variety which differ greatly; there are trees of Wealthy which have better crops of better colored fruit than do trees of the same variety in the same row. What causes this difference? The difference in the individuality of the trees, we believe, accounts for this difference in the habit of fruiting. This is the case in animal life; the Jersey is a good dairy breed of cows, and yet not every Jersey is a good cow. It is the individuality of horses which makes the get of one sire better than the get of another. It is this characteristic which makes improvement of breeds possible. Now the best orchardists of the country are recognizing this difference in the individuality of trees. Nursery trees propagated from bearing trees of known value, which bear regular crops of good fruit, are sought after by the most thoughtful planters. Every farm boy early learns the trees in his father's orchard which bear the best fruit every year; the close observing boy often learns eren the branch on that tree which bears the very choicest of fruit. Why not propagate from this tree and from this particular branch, and thus get other trees like it?

This is the work we are carrying on and our growing stock has been propagated from scions cut from selected trees. The time is coming when every one will appreciate the value of these trees: now is the time to start an orchard of this character.

Our shipping season usually begins early in April and continues as long as stock can be safely handled.

Center Point is located on the Decorah branch of the Chicago, Rock Island \& Pacific Railway, 18 miles north of Cedar Rapids.

Our office and grounds are located two miles southeast of depot on main road to Cedar Rapids or Marion.

We make no charge for boxing or baling, the prices quoted are for stock packed and delivered on board the cars here at Center Point.

GUARANT모.-We exercise great care to keep our varieties true to name, and are ready at any time to replace any stock that may prove untrue, or, refund the amount paid for the same, but it is mutually agreed that we are not to be held liable for any amount greater than the original price of the goods.

CONDITION.-We accept all orders on condition, that they shall be void should any injury befall our stock from hail, frost, storm, fire or other causes over which we have no control.

ORDFR FARIY.-A great deal is gained by sending in your order early. We can do better by early orders than by those that come in right in the rush of digging and packing time. 


\section{General Directions to Correspondents.}

The attention of our customers is respectfully called to the following directions, which will, if followed, be an aid to purchasers as well as to ourselves:

Prices given are for quantities specified, but 6 will be furnished at dozen rates, 50 at 100 and 500 at 1,000 rates.

The above applies only where the quantity talsen is of one rariety.

Order early, it will greatly facilitate shipment if orders are sent in early.

Customers are requested to give full shipping directions, stating when stock is wanted, and whether by freight, express or mail, and via what route, if there is a choice. In absence of instruction we will use our best judgment. When ordeling always specify-size and price of stock wanted.

All mistakes of ours will be rectified as soon thereafter as opportunity will lermit.

Terms cash or satisfactory security in all cases before shipment to strangers.

Remit by postoffice money order on Center Point, Iowa; registered letter, bunk draft, or express money order. Fractions of a dollar will be accepted in 2-cent postage stamps.

Address all letter's and make all remittances payable to $\mathrm{S}$. Wr. Snyder, Center, Point, Linn county, Iowa. Telegraph office, Center Point, Ia., also telephone connections.

When plants are to be sent by mail, it must be so stated in the order and the necessary amount for postage included in the remittance.

All orders will be racked in the very best possible manner and safe arrival guaranteed.

Remember that when you order your trees from our catalouge you are not paying agent's commission, traveling expenses, hotel and livery bills, etc. etc., in addition to a fair price for the goods.

Our prices are as low as first-class stock can be sold. Good stock put up in the very best shape cannot be sold at shoddy prices without loss to somebody. Cheap stock, as a rule, means poor stock. No one can afford to buy poor nursery stock of any kind.

We do not aim to sell trees for the smallest possible amount of money, but we do aim to give every customer the full worth of his money, and the greatest possible satisfaction.

Our stock is the product of Iowa soil, is adapted to this climate, and guaranteed to be true to name.

We use none of the wonderful methods of propagating nursry stock of which we so often hear exploited by the traveling tree agent. Suffice it to say we use for propagation the best methods known to the professional nurseryman.

We offer you the very best trees that can be produced, and at the lowest price consistent with the highest quality. The best is always the clreapest. Printing and distributing catalogues is expensive, and it cannot be kept up long unless it pays the nurseryman, and it will not pay him unless it pays the planter. Talue for value is our rule.

The hospitality of the place is open to visitors and tree lovers and those in need of nursery produce are cordially invited to call and see us or correspond about their wants. Information cheerfully given and descriptive catalogue mailed to all applicants. 


\section{Apples.}

While various other fruits have been crowded upon the attention of fruit growers during the past decade, yet among progressive orchardists the apple easily holds its position as the king of fruits, and with the intelligent treatment will return as great profit to the planter as any fruit grown in the temperate zone. Most other fruits are in condition to use only temporarily, but making a judicious selection of summer, fall and winter varieties, one can provide himself with apples the whole year through. They can be eaten at the home fireside or shipped to the uttermose parts of the earth without being injured or in any wise losing their flavor. Our stock of apple trees for this coming season is much the largest we have yet produced; they are smooth, thoroughly sound and fine, and comprise the most approved varieties for planting in this section of the country.

For a family orchard we would not recommend the planting of many varieties. A few of the best sorts is quite sufficient, if judiciously selected, to afford a succession of fruit throughout the year, for home and market.

Persons selecting trees for transplanting will find it to their interest to choose small, thrifty trees two or three years old, and from four to seven feet high as such are more safely transplanted, and with more satisfactory results than older and larger trees.

Our apple trees are all two and three years old, grafted by the best approved method, with the end in view to produce the tree best adapted to withstand the rigors of this climate.

Prices on Apple Trees will be as Follows, Except Where Otherwise Noted. Price Iist of Apple Trees, Ixcept as Otherwise Noted.

each doz. per 50 per 100

1 st-class, 2 and 3 years, 5 to 7 feet.......\$0.30, \$3.00 \$12.00 $\$ 22.50$

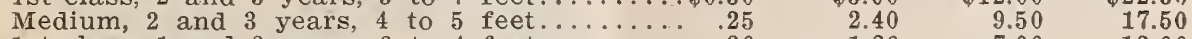

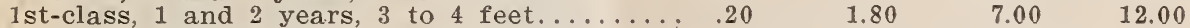

6 at $d o z, 25$ at 50 , and 50 at 100 rates, the above rates to apply only when the quantity taken is of one variety, 6 of a variety at doz. rates, and lesser quantities at piece rates; orders for 25 to 50 trees containing a long list of varieties cannot be filled at 50 and 100 rates.

\section{Select Summer Varieties.}

YELIOW TRANSPARENT.-In locations not much subject to blight (with us has never been seriously affected) this is valuable for home use or market, as the fruit is earlier, larger, handsomer and better than the old Early Harvest, imported from Russia by Department of Agriculture, Washington, D. C. 5 to 7 feet and 4 to 5 feet.

RED ASTRACHAN.-A fruit of extraordinary beauty. Tree healthy and hardy; bears abundant crops of handsome dessert fruit; flesh white, crisp, with an agreeable acid flavor; last of July to middle of August. 5 to 7 feet and 4 to 5 feet.

TETOFSRY.-One of the most extremely hardy Russian summer apples. Tree an upright, rather slow grower; comes early into bearing and produces annually. Flesh juicy, sprightly, acid; fragrant and agreeable; July and August. 5 to 7 feet, 4 to 5 feet and 3 to 4 feet.

GIPSEY GIRI.-A perfect tree in nursery and orchard and proving an early and full bearer of large sized, remarkably handsome and good fruit; season late summer. 5 to 7 feet and 4 to 5 feet.

THAIFR.-One of the leading Russian varieties. Tree of moderate growth and good form, very early bearer, small trees often bearing in nursery rows. Frut medium pale yellow; flesh white, tender, juicy, with brisk sub-acid flavor. Season, July and August. 5 to 7 feet and 4 to 5 feet.

*RUBETS or IIVFIAND RASPBFRRY.-This we obtained at our experiment station at Ames under the name Rubets, but we find several other nurseries are propagating it under the name Liveland Raspberry, no matter which is correct it is our very best and earliest summer apple, will keep in perfect condition longer than any early apple we have knowledge of. Tree a slowe grower; early, regular and profuse bearer; very hardy; of Russian origin. 5 to 7 feet, 4 to 5 feet and 3 to 4 feet.

DUCHESS OF OIDENBURG.-A hardy Russian variety; fruit of large size, flavor slightly sub-acid; indispensable in the north. One of the most desirable sorts for market or domestic use; last of August and September. 5 to 7 feet and 4 to 5 feet. 
SWFFT JUNF.-An old variety, highly prized for the good quality of its fruit. Tree medium hardy, fruit of medium size, flesh yellowish, very sweet, not very juicy, but pleasant and rich. 5 to 7 feet and 4 to 5 feet.

BFNONI.-Fruit of medium size, red striped, tender and juicy, best of its season. Tree reasonably hardy, of upright form, very productive; season, August. 5 to 7 feet and 4 to 5 feet.

The following varieties can be furnished for early orders in 5 to 7 feet and 4 to 5 feet grades: Beautiful Arcad, Early Sweet, Early Harvest, Early Strawberry, Golden Sweet, Noble Red Streak, Nickner Strawberry, Red June, Repka, Kislaya, Summer Queen, Summer Rambo and Yellow Sweet.

\section{Fa11 Apples.}

IRISH PEACH.-A good tree, hardy and fruitful, a splendid dessert apple, whitish yellow, beautifully blushed next the the sun, juicy, pleasant acid, aromatic. Season just after Duchess. 4 to 5 feet only.

MCMAHAN'S WHITE.-Tree vigorous, a regular bearer, very productive; fruit smooth, whitish, sometimes with a pale tint of red in sun; flesh white, crisp, tender, juicy, sub-acid, good, valuable for market, cooking and dessert. 5 to 7 feet and 4 to 5 feet.

WIAITHY.-A native of Minnesota, where it has proved hardy, vigorous and very productive. beautiful and excellent fruit. Flesh white, fine, sometimes stained with rea; tender juicy, vinous, lively subacid. September to December. The most heartily recommend this variety. 5 to 7 feet and all smaller size.s.

UTTPR'S. RED. - Medium to large, roundish, whitish red, very good quality, one of our best fall apples. September to October. 5 to 7 feet and 4 to 5 feet.

IONGFIEID. - One of our best Russian varieties. An early and prolific bearer of most excellent fruit. Rich, sprightly sub-acid quality, medium size, yellow, with a decided blush. October. 5 to 7 feet and. 4 to 5 feet.

PATTEN'S GRFENING.-A seedling of the Oldenburg and its equal as an orchard tree in hardness and bearing; large, uniform in size, pleasant acid, good cooking, and the best for drying, having yielded the greatest number of pounds of dried fruit per bushel of any other variety. Season, September and October. 5 to 7 feet and 4 to 5 feet.

WOIF RIVER.-A very remarkably large, fine looking fruit, but coarse grained and sour; good for culinary use and to exhibit at fairs, for its large size; tree healthy and hardy. 5 to 7 feet and 4 to 5 feet.

FAII ORANGF.-A very strong, erect grower; hardy, regular and abundant bearer; flesh white, tender, juicy, sub-acid, one of the best for cooking; very profitable here. 5 to 7 feet and 4 to 5 feet

PIUM'S CIDER.-A splendid late fall varlety, does not bear quite so young as most other kinds, but makes up for it when it gets at it; good size; flesh whitish, tender, juicy, mild sub-acid. 5 to 7 feet and 4 to 5 feet.

HIBERNAI.-A large, sour apple, good only for cooking, for which they are valuable; Russian origin, very healthy and hardy. 5 to 7 feet and 4 to 5 feet.

FAMFUSE OR SNOW.-Tree vigorous and productive, fruit small to medium, roundish, very handsome, deep crimson; flesh snow white, tender, juicy, high flavored and delicious. One of the finest dessert fruits. November and December. 5 to 7 feet and all smaller sizes.

SILRENLEAF.-By all odds the hardiest tree in our list, standing on its own roots nothing in the way of hard winters has yet affected it, a large sour fruit good for culinary purposes, season, September. I grow it principally as a stock on which to top-work Ben Davis and other semihardy varieties. 5 to 7 fert and 4 to 5 feet. 
The following varieties of fall apple trees can be furnished for early orders in the 5 to 7 feet and 4 to 5 feet grades: Agnes, Alexander, Autumn Strawberry, Bell Flower, Cole's Quince, Fall Rambo, Hass, Kirkbridge, Lowell, Maiden Blush, Penn, Red Streak, Prolific Sweeting, Red Beitigheimer, Sweet Pear and Vassils Largest.

\section{Winter Apples.}

ALIFN'S CHOICF.-A medium sized apple of excellent quality; flesh white, stained with red, crisp, juicy, aromatic, good, keeps all winter. Tree a young bearer, good grower and hardy. 5 to 7 feet and all smaller sizes.

ANAFTTE-(Black Annette.)-Tree of free, slender growth, very productive, extremely young bearer; fruit of medium size, striped with dark red on dull green, with numberless grey dots. Flesh greenish white, juicy, subacid, firm and one of the best keepers. Season, February to June and latr. You will not be disappointed if you plant liberally of this variety. 5 to 7 feet and all smaller sizes.

BAIIEY SWEFT-Tree not of the hardiest, but enough so to be valuable here; a profitable friuter, flesh white, tender, not very juicy, almost melting, with a honeyed, sweet flavor, very fine for those who like a sweet apple. Late fall and early winter. 5 to 7 feet and 4 to 5 feet.

BFA DAVIS.-Large, smooth, nearly covered with red; sub-acid, one of the best market sorts. Tree vigorous and healthy and while not the hardiest, it rarely ever dies in debt to the planter. Should have a place in every orchard. Plant it and keep plantıng it. All sizes up to 7 feet.

CANADA BAIDWIN,-Tree hardy, thrifty, vigorous, upright grower, fruit handsome and of good quality; flesh white, fine tender, juicy, refreshing, with a mild sub-acid flavor; keeps all winter. 5 to 7 feet and 4 to 5 feet.

CARPFATrR'S CHOICE.-A seedling originated here in Linn county. Tree perfectly hardy, fruit about the size and color of a well-grown Whitney No. 20 crab. In fact, the originator at first called it Winter Whitney; because of its close resemblance to the above variety in color, size and eating quality; keeps well into winter with common care. 5 to 7 feet and 4 to 5 feet.

DOMINIx.-This variety was at one time extensively planted; and we frequently find an old tree of this variety which very forcibly reminds us that it is yet worth planting. Reasonably hardy, rapid grower and early bearer, branches being literally weighted down by the rope-like clusters of fruit; keeps throughout winter. 5 to 7 feet and 4 to 5 feet.

GRIME'S GOIDEN.-Tree vigorous, reasonably hardy, upright, spreading, very productive, flesh yellow, rich, sprightly sub-acid, highly prized for its uniform regular annual crop. December and later. 5 to $7 \mathrm{feet}$, and 4 to 5 feet.

GRFrirvIIIF.-Downing's Winter Maiden Blush, new, from seed of the popular Fall Maiden Blush, which it closely resembles in size, color, flavor and productiveness, but it is a better grower and keeps all winter. We have been growing it for several years and are well pleased with its behavior, 5 to 7 feet and 4 to 5 feet.

GANO--Originated in Missouri; hardier than Ben Davis, fruit keeps as well and is of brighter color. Tree strong upright grower. 5 to 7 feet and 4 to 5 feet.

HARRY KAUMP.-Medium; yellow; quality good; early and constant bearer. Tree vigorous, very desirable at the north. November and December. 5 to 7 feet and 4 to 5 feet.

IOWA BIUSH.-One of the most valuable sorts for home use. Tree hardy and vigorous; a splendid dessert or cooking fruit. Fruit size of Jannette and very handsome. Season, November to April. 5 to 7 feet and 4 to 5 feet.

ISHAM SWEET.-Originated in Wisconsin, where it is highly recommended. New here, but promising. 5 to 7 feet only.

ISHFRWOOD.-An Iowa Ironclad, upright, vigorous grower; very productive and valuable; fruit large and handsome; flesh rich and excellent; season, late winter. Prices, 5 to 6 feet, $35 \mathrm{c}$ each. 4 to 5 feet, $30 \mathrm{c}$ each; 3 to 4 feet, switches, $25 \mathrm{c}$ each.

JORDAN.-The scions of this variety we obtained from one of the oldest orchards in this part of the county. The old tree must have been between thirty and forty years of age at the time we cut our first scions, it having just borne an enormous crop of the largest and finest looking winter fruit we ever saw grown in this section; we could get but few scions, consequently have made slow process at propagating. We will offer only a few trees of this variety as follows: 5 to 7 feet, $50 \mathrm{c}$ each; 4 to 5 feet, $40 \mathrm{c}$ each; all to be two years old.

JONATHAN.-A very beautiful dessert apple. Its great beauty, good quality and productiveness in all soils unite to recommend it to all orchard growers. While the tree is not strictly hardy, we think it the very best apple that grows. November to February. 5 to 7 feet and 4 to 5 feet. 
IANSINGBURG.-Of red Romanite type. Tree as hardy as Roman Stem: flesh firm, sub-acid, good. Valuable mainly for its long keeping qualities, will keep with common care the year round. All sizes up to 7 feet.

MAIINDA.-This tree is one of the hardiest of Amerlcan varieties, a great faree of medium growth, spreading top. Fruit medium to large, sub-acid flavor. Season January to May. All sizes up to $7 \mathrm{feet}$

MONN.-A seedling originated here in Linn county. The original tree was broken down by a wind storm at upwards of 40 years of age; at one time this tree produced 15 barrels of choice fruit at one picking; large to very large, whitish green with blush next to the sun; mild, sub-acid, keeps all winter; tree spreading and very thrifty, will be profitable in this locality. 5 to 7 feet and 4 to 5 feet.

MISSOURI PIPPIN.-Large, oblong, bright red, with numerous gray dots; very handsome and of good quality; an early and abundant bearer, a hardy, vigorous and desirable variety for this locality. Deccember to March. 5 to 7 feet and 4 to 5 feet.

NORTHWEST GREFNING.-A good commercial variety, originated in Waupaca county, Wisconsin. A large, handsome green apple, changing to yellow when fully ripe. One of the best keepers yet produced. Quality very good. Tree a strong grower and very hardy, grows in favor each succeeding year. We strongly recommend this variety. All sizes up to 7 feet.

PFWAUKFE.-A seedling from Duchess of Oldenburg. Tree strong grower and very hardy, fruit medium to large, round, obovate, waved. Surface, bright yellow, partially covered with dark red, striped and splashed, covered with a gray bloom overspread with whitish dots. Flesh yellowish white, juicy flavor, sub-acid, rich, good to best. 5 to 7 feet and 4 to 5 feet.

PARADISE WINTER SWEET.-This is a productive and excellent orchard fruit; a great favorite with those who love sweet apples. Tree reasonably hardy, upright, vigorous, but not a very heavy bearer; smooth, yellow, fine appearing fruit.

ROMAN STEM.-A beautiful apple, medium to large; rich, pleasant, musky flavor, dessert. Tree hardy, a slender grower, regular bearer and reasonably productive. An old variety which continues to grown in favor; will keep all winter; very desirable for home use. All size up to 7 feet.

RAWLES' JANFTTE OR JANITON.-Not considered very hardy, but because of other good qualities it is still being planted; a late bloomer, avoiding the late frosts in spring; flesh rich and refreshing. Season, February to June. 5 to 7 feet and 4 to 5 feet.

ROYAI FENRY.-A seedling originated in this neighborhood and we believe to be worthy of trial; a good keeper, above medium size, light red color all over. Tree upright thrifty and hardy. 5 to 7 feet and 4 to 5 feet.

RAMSDELI SWEET.-This old variety is esteemed for the large crops which it bears and as a showy sweet apple for market and home use. Tree very vigorous and comes early into bearing; flesh very tender, mellow, unusually sweet and rich. October to February. 5 to 7 feet and 4 to 5 feet.

SAIOME.-Flesh whitish yellow, fine, tender, mild slightly aromatic, good; its hardiness, long keeping, good quality, uniform size, retention of its flavor quite late, even ipto summer, will no doubt make it valuable for the west and northwest. 5 to 7 feet and 4 to 5 feet.

SHERIFr.-Tree vigorous and very hardy; one of the most satisfactory varieties yet planted in this section; fruit medium to large; usually highly colored; splendid quality; bears early and regular crops. Season December to February. 5 to 7 feet and 4 to 5 feet.

SCOTT'S WINTER.-Medium size, striped with red; tender yet firm; one of the best keepers, very hardy, good grower and very productive. January to March. 5 to 7 feet 4 to 5 feet.

TALMAN SWEFT.-Tree an upright, spreading grower, vigorous and quite hardy; color greenish yellow with blush on sunny side; flesh quite white, rather firm, fine-grained with a rich, sweet flavor. November to April. 5 to 7 feet and 4 to 5 feet.

*TOBIAS RAUCH.-A very promising seedling, originated here in Linn county. It has some of the characteristics of the Hyslop crab, which we believe to have been one of its parents. Tree apparently as hardy as a crab; reasonably young bearer; fruit large and as dark colored as a Hyslop crab; flesh partaking somewhat of the nature of the above crab, but more juicy and of pleasant flavor. Season March to June. Worthy of trial. Prices, 5 to 6 feet, 50 cents; 4 to 5 feet, 40 cents.

WIIIOW TWIG.-Large, roundish, greenish yellow, striped with dull red. Flesh firm, rather coarse, pleasant sub-acid flavor, most valuable for kitchen use. Profitable and popular as a long keeper and market sort. 5 to 7 feet and 4 to 5 feet.

WAIBRIDGE.-Above medium size, striped with red, handsome and of excellent quality, vigorous grower and very productive in Rocky Mountain regon. January to May. 5 to 7 feet and 4 to 5 feet. 
WINTER STREIFIING.-Prof. Budd says of this variety: "It is so much like the Walbridge in its markings, shape and color, that it probably belongs to the same family; but the fruit averages much larger, is better in quality and a great bearer, also a good keeper; behaves well in nursery and we think it worthy of trial. 5 to 7 feet and 4 to 5 feet.

WINTER SNOW.-Here is an apple that for quality, flavor and texture of flesh is extctly like the common Fameuse, fruit about the same size but not near so highly colored and will keep until spring; this is a great acquisition to lovers of the snow apple. I have been grafting of this variety (sport it might. properly be called) from an old tree propagated by Prof. Budd many years ago which is still thrifty and fruitful. 5 to 7 feet and 4 to 5 feet.

YORK IMPERIAI.-Medium to large; yellow, shaded red; firm, juicy, subacid. An excellent shipping apple.

The following varieties of winter apple trees can be furnished for early orders in 5 to 7 feet and 4 to 5 feet grades: Arkansas Black, Big Rambo, Champion, Coffelt, Gillaflower, H. Nonesuch, Huntsman, Ingram, Iowa Beauty, King of T. Co., Magog Red Streak, McIntosh Red, 'Mam. Black Twig, Minkler, Northern Spy, Peerless, Price's Sweet, Regal, Repka Malenka, Rhode Island Greening, Rome Beauty, Seeknofurther, Smith's Cider, Stark, Tulpehocken and Wine Sap.

\section{Select Crabapples.}

A good assortment of these hardy and beautiful trees should be among first things planted. Are perfectly hardy and may be delied upon to furnish abundance of fruit suitable for a great variety of purposes. In our list of crabs are some of the finest eating apples to be found in the apple family. Plant them for the children; they are the special delight of the small boy. Don't allow him to go unsupplied.

Price of crabapple, except as otherwise noted, will be the same as for apple trees of same size.

BRIAR SWEFT.-Fruit above medium size, flesh yellowish, crisp and juicy; very sweet, makes the very richest cider, quality best for dessert or preserves. Tree hardy, vigorous and productive. 5 to 7 feet and 4 to 5 feet.

EXCEISIOR CRAB.-A beautiful new, hary variety, originated with Peter M. Gideon of Excelsior, Minn. It is a seedling of the famous wealthy apple, which it resembles in quality, and is a strong, handsome-growing tree. Ripens in early fall, a little after the Duchess of Oldenburg; the handsomest, hardiest and best of our new crabs. 5 to 7 feet and 4 to 5 feet

*GIBB CRAB.-Color deep yellew, originated in Wisconsin. In size, beauty and excellence it is the best yet tested. Tree with good foliage and not given to blight. Flesh yellow, crisp, juicy, and just enough of astringency to make it useful for the purposes for which crabs are grown. An excellent eating apple in its season, September. Price, 2 years, 3 to 4 feet, 25 cents.

HYSIOP CRAB.-This variety has been long and extensively cultivated. The trees are hardy and growth strong, inclined to blight seriously in certain locations; fruit large, produced in clusters, flesh yellowish, sub-acid, good for culinary use; color, dark red.

GFNERAI GRANT CRAB.-Tree an erect, vigorous and handsome grower, fruits'in dense clusters. A regular and profuse bearer, quality good. 5 to 7 feet and 4 to 5 feet.

IMARTHA CRAB.-Said to be a seedling of Duchess of Oldenburg, resembles Transcendent in shape and size, but more beautifully colored; bears enormously, and so far has been perfectly free of blight; a model tree in every way; makes the finest jelly and sauce. 5 to 7 feet and 4 to 5 feet.

SUIARD CRAB.-The largest of this class of apples, (a native wild crab;) very valuable as a cooking apple; when cooked a fine quince-like flavor; keeps well until July. Tree very productive and hardy as any wild crab. 5 to 7 feet and 4 to 5 feet.

SWRET RUSSET CRAB.-Fruit large, pale yellow, slightly covered with russet; flesh exceedingly rich and sweet; a delightful eating apple for the children. Tree slow grower, hardy and productive; price, 4 feet, 25 cents; 3 to 4 feet, 20 cents.

WHITNEY'S SEFDING NO. 20.-A valuable and beautiful crab. Tree very hardy; enormously productive and seldom fails to bear. The very finest grown for cider and excellent for jellies, etc. 5 to 7 feet and 4 to 5 feet.

The following varieties of crab apples can be furnished for early orders, in grades, 5 to 7 feet and 4 to 5 feet: Alaska, Florence, Gideon's Best, Transcendent, Virginia and Washington. 


\section{Select Pears.}

Te would not advise to plant pears extensively in this part of the state while we know of many instances where they seem to be a success, yet we would only offer them for trial, and those finding their soil and location adapted to the growing of this most luscious fruit, can plant of them more extensively as they grow in experience. Our list is made up of the most promising varieties, many having been discarded.

GOIDEN RUSSFT PEAR.-This unique variety promises to be of great value in the south half of Iowa; its peculiar thick, leathery foliage renders it free from blight. It is proving a young and heavy bearer of fruit; above medium size and good quality. Price, 5 to 7 feet, 40 cents; 4 to 5 feet, 30 cents; 3 to 4 feet, 25 cents.

IONGWORTH.-A very hardy seedling pear of recent introduction, originated at Dubuque, Iowa, 40 years ago, by $\mathrm{Wm}$. Longworth. Tree a strong upright grower, entirely free from blight and an enormous bearer. Flesh rather coarse, juicy, sugary, good flavor; ripens 1st to middle of September. Price, 5 to 7 feet, 40 cents; 4 to 5 feet, 30 cents; 3 to 4 feet, 20 cents.

MONGOIIAN SNOW PEAR.-The hardiest and best of all the chinese varieties. Its leares are always clear, handsome and perfect; will prove valuable up to the 42 nd parallel. It is a profuse bearer and when ripened in the house much better than Keiffer's and is blight proof. Price, 5 to 7 feet, 40 cents; 4 to 5 feet, 30 cents; 3 to 4 feet, 25 cents.

KEIFIFR'S HYBRID PFAR.-A cross between the Bartlett and Chinese Sand Pear. This has been so widely tested with favorable results that it is now regarded as a standard fruit, with us has never shown any trace of blight. Fruit measures 10 to 12 inches round; flesh white and firm, juicy and rich, with pleasant flavor and good quality; will keep through November. Price, 5 to 7 feet, 35 cents; 4 to 5 feet, 30 cents; 3 to 4 feet, 20 cents.

BFZIA DE IA MOTTE-Avariety introduced by the Iowa Agricultural College, at Ames, has proven very fruitful in Linn County, especially at Mt. Vernon. Price, 5 to 7 feet, 35 cents; 4 to 5 feet, 25 cents.

\section{Can We Grow Peaches?}

The following varieties can be furnished for early orders in grades, 5 to 7 feet and 4 to 5 feet at same price as Golden Russet, Flemish Beauty, Garber, Rosney, Vermont Beauty, Wilder and Worden Seckle.

CAN WE GROW PEACHES?

The recent mild winters, coupled with the introduction of the hardier varieties, have removed the heretofore supposed boundaries of the peach growing belt much farther north than the limits heretofore prescribed, and we now find ourselves successfully growing this excellent fruit, with brighter prospects ahead. The recommend the following varieties for trial:

Our peach trees are all budded upon the hardiest stock in existence, namely seedlings produced from native grown seed of the Bailey Peach. We plant them about a foot deeper than they stood in the nursery so that if ever the tree is lzilled back to the ground it will throw up a sprout from above the bud union and thus renew the tree. Price of peach trees as follows, except as otherwise noted: 5 to 7 feet, $30 \mathrm{c}$ each; 4 to 5 feet, $25 \mathrm{c} ; 3$ to 4 feet, $20 \mathrm{c}$.

BAILFY. - The Friday Seedling or Bailey Peach has a record of sixty years and still fruiting; has borne three crops out of five since planted. In Cedar and ajacent counties it has borne heavy crops for many years in succession; fruit above medium size, a free stone with small pit and white flesh; season medium early. Price, 4 to 5 feet, $25 \mathrm{c}$ each, only.

IONE TREE.-The original trees of this variety have stood 20 vears in Jchnson county, Iowa, without protection, having withstood 32 degrees below zero unharmed; has produced crops of fruit on an average every other year for this time; fruit is medium size, iarge specimens having measured $81 / 2$ inches and 9 inches in circumference. color, yellow inside and out, without any blush; pit very small; ripens about September 10 th. We regard this variety as most promising for success in Linn county. 5 to 7 feet, 4 to 5 feet and 3 to 4 feet.

IFIGH PEACH.-Here is a Linn county peach tree with a great record. The original tree stands in Mount Vernon on the grounds of Mr. Leigh; eleven years old; began fruiting at the age of four years; the stem of the tree is 34 inches in circumference, 24 feet high and 20 feet spread of top; has produced sixteen bushels of peaches all told; it best record, eight measurer bushels of fine fruit in a single crop; fine specimens measure $101 / 2$ to $11 \mathrm{t} / 2$ inches in circumference and weigh $10 \frac{1}{2}$ ounces, freestone and of excellent quality. Our stock of trees are as fine as can be produced and will please you. 5 to 7 feet only, $50 \mathrm{c}$ each. 
*MYgRS PEACH.-This is a rich yellow fleshed fruit, largest speciment measuring nine inches in circumference; five crops in succession is the record of the original trees, beginning with 1997 to and including 1901 ; passed the test of

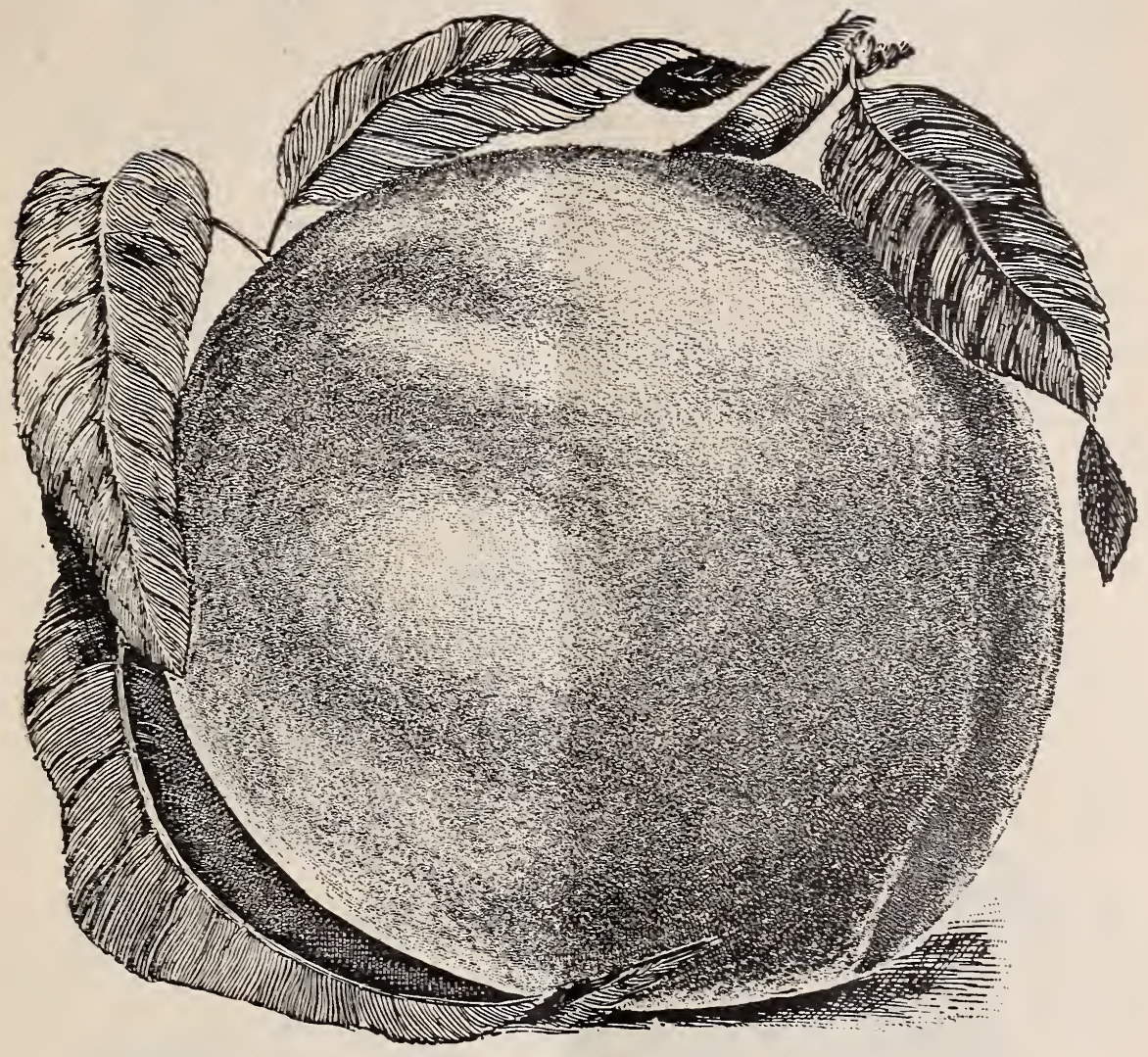

Myers Peach,

winter of 1598 and 99 without protection and produced a crop the following season. This peach made the above record at Centerdale, Cedar county, Iowa, where it originated. Price, 5 to $i$ feet, $40 \mathrm{c}$ each; 4 to 5 feet, $30 \mathrm{c}$.

\section{Plums.}

Our experiments in plum growing have been at a standstill this season except that our orchard is in excellent condition for next year, having taken a rest. which we think is beneficial after having borne such a tremendous crop as it did last year. Te have gathered up many new varieties out of which we expect some good results and look forward to recording their good qualities in subsequent issues of this list. Our notes on plums in this issue are based principally upon the experience of last and previous seasons. The plum is in its native element in Iowa soil and climate, this section having been farored with mant choice varieties in its rimitive state.

We are making this fruit a specialty and our experimental orchard is our delight; up to the present we have planted in it about 250 varieties many of which have been discarded. It is our aim to test all varieties which come well recommended and only hold fast those which are good, and our customers shall have the benefit of our experiments. Do not deceive yourself by thinking you can plant a lot of plum trees in an old dry, soddy patch and they will board themselves, work for nothing and rield bountiful crops of luscious fruit; if you do, you will be most certainly disappointed. Give them your best land and as good and frequent cultivation as you ought to your corn field or garden and you will succeed. In the following descriptions we will group the different families by themselves, beginning with those varieties belonging to the American group. which embraces all varieties native to or descended from varieties originally found in the northwestern portion of the United States-Iowa and Minnesota, in particular. The varieties belonging to this group are the hardiest in tree and bud of ansthing in the plum line. 
Price of P1um Trees as Follows Except as Otherwise noted:

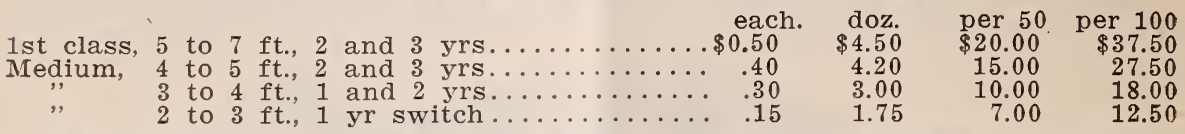

Six at dozen 25 at 50 and 50 at 100 rates; the above rates to apply only when the quantity taken is of one variety; six of a variety at dozen rates, and lesser quantities at piece rates; orders for 25 or 50 trees containing a long list of varieties cannot be filled at 50 and 100 rates.

\section{Americana, or Native Group.}

SNYDER.-Originated by J. H. Fairchilds. Linn county, Iowa. This has proved to be the most productive large plum of good quality we have yet tested; will carry the heaviest crop of uniformly large fruit of any variety we have seen. Tree a strong grower with the best of foliage. 5 to $7 \mathrm{feet}$, and 4 to 5 feet.

HAW KEYE.-Large to very large, roundish, oblong, thick skin, a little coarse in flesh, rather firm, grayish purple. Tree of spreading habit, inclined to droop; hardy and productive. Season, last of August. Many call it the best plum in cultivation. 5 to 7 feet only.

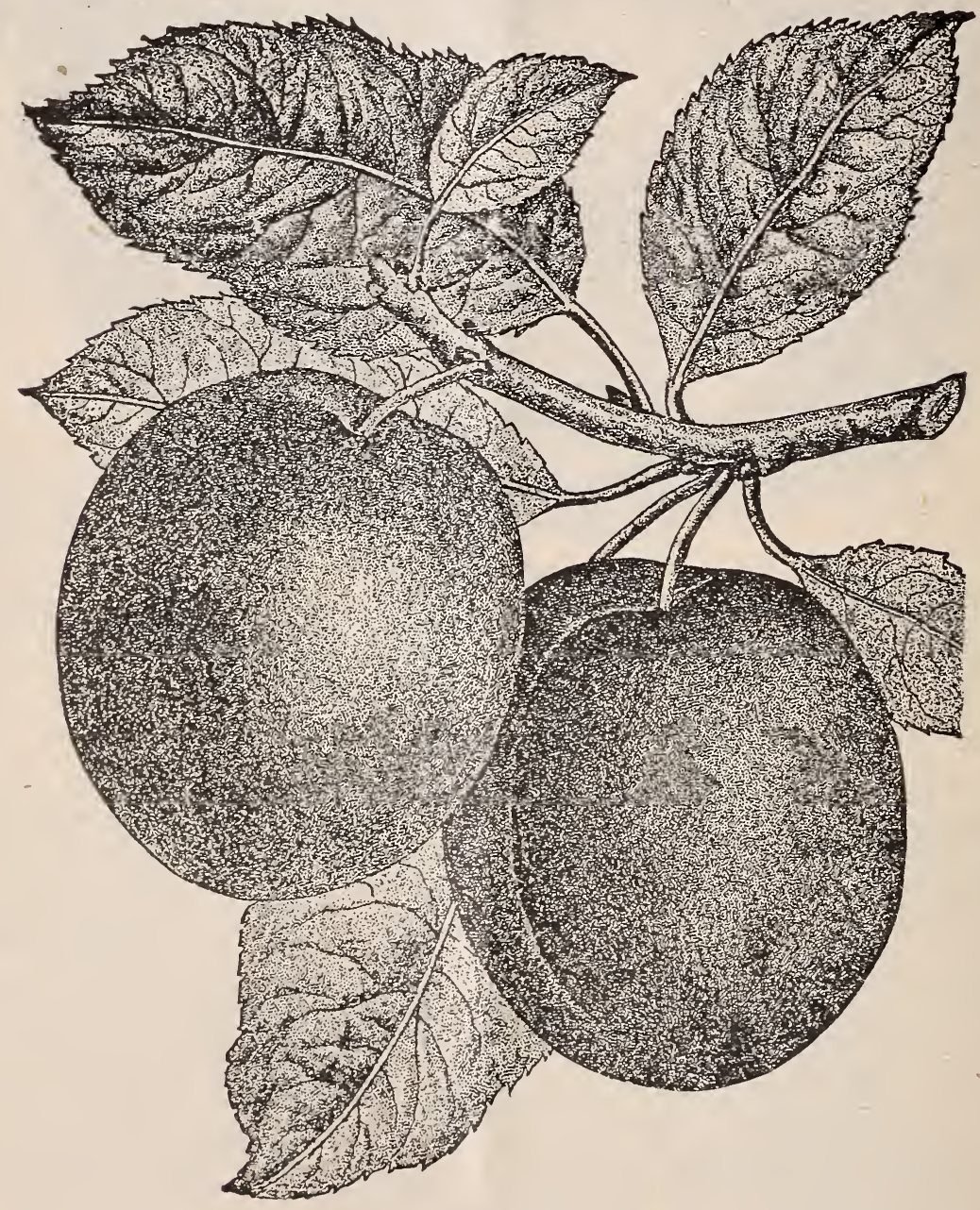

Hawkeye Plum.

WOLF.-Large, dark red, good quality for dessert; develops too much acid, when cooked; vigorous grower and abundant bearer. One of the best. 5 to 7 feet and 4 to 5 feet. 
BEATTY.-This plum originated in Benton county, Iowa, and bears the name of its originator. A beautiful, upright tree, with the best of foliage, hardy and thrifty. Fruit large to very large, beautifully colored, transparent yellow, biushed with red. Quality as good as DeSoto for any purpose. This plum combines more good qualities than any we have yet fruited. Season, last of August. Prices, extra fine, 7 to 8 feet, $75 \mathrm{c}$ each; 6 to 7 feet, $60 \mathrm{c} ; 5$ to 6 feet, $50 \mathrm{c} ; 3$ to 5 feet, $40 \mathrm{e}$;

DE SOTO.-Here is our old stand-by. To this we can compare everything else as a standard of quality. They are as good as peaches when canned and one will not tire of them so soon. Its only fault is overbearing-should be thinned for best results. Cultivate or mulch this variety and pick off fully one-half the fruit soon after the ffruit has set and the grower will be richly rewarded. Medium to large, vary in color from yellow to purplish red. Season, middle to last of August. 5 to 7 feet, 4 to 5 feet and 3 to 4 feet.

WYANT.-The best dessert plum among the natives. Peel and serve with cream and sugar, in their place, or, to eat out of hand fresh from the tree; however, many think it one of the best for canning also; develops too much acid in cooking to suit us for that purpose; thick skin which peels readily, leaving a toothsome morsel, which is sure to call for more; freestone, purplish red, large, round, oblong; very prolific and extremely hardy. 5 to 7 feet only.

FAIRCFIID.-Considering the heavy crops produced upon young trees, this is the largest native we have any knowledge of. Originated here in Linn county, and bears the name of its originator. It is a hybrid of Desoto and a fine large wild plum from Nebraska. Very prolific, a three-year-old tree having borne a peck of plums averaging larger than Hawkeye and of much better quality. Color much the same as DeSoto, but not so bright. Season, middle of September. 5 to 7 feet only.

FOREST GARDEN.-Large, purplish red on orange; very productive and a good fruit. 5 to 7 feet.

FAAG PIUM.-A native of fine quality and said to be a good bearer. Two years, 5 to 7 feet; 1 year buds, 3 to 5 feet.

CHENEY.-Large, round, oblong, dull purplish red with thick skin; firm, sweet, good. Middle of August. 5 to 7 feet only.

CHAMPION.-Very large, dark red, round, inclined to oblong, good for culinary use; very productive. 5 to 7 feet.

\section{Miner Group.}

The varieties comprising this group are all comparatively late in ripening, about as hardy as those of the Americana group, and uniformly productive of large, beautifully colored fruit of best quality. They are about all self sterile, but the kinds effectually pollinate each other, if thoroughly mixed when planted in the orchard. As there is little difference in time of blossoming, plant a tree of one variety and then another, and so on, mixing the different varieties as much as possible, then you will be assured of perfect pollination.

SMITH'S RFD.-A bright red plum, a little above medium size, about same shape as miner, about two weeks earlier; one of the very best in our list for culinary use. 5 to 7 feet and 4 to 5 feet.

FOREST ROSE.-Larger than Miner and of superb quality for culinary use; not quite so hary as Miner and should not be planted much north of here; should be includedein every collection for this section. 3 to 5 feet.

HANSON.-A medium-sized, dark red plum of good quality; tree very hardy and productive; medium early, ripening at a time when few other plums are ripe. 3 to 5 feet.

MINFR.-This is an old standard variety almost to well known to need description. Many regard it as a shy bearer, which is due to lack of proper pollination; when planted in an orchard among many other varieties it bears regular and very heavy; large, round, dull red, clingstone; late and profitable.

PRAIRIP FIOWFR.-Large, round, dull red, clingstone; good judges pronounce this the best of the group, which certainly strongly recommends it to all lovers of this class of fruit. 3 to 5 feet.

\section{The Wayland Group.}

Another season's experience has convinced us that some of the very best plums in existence are to be found in this group. A trial by any skillful housewife is all that is necessary to convince the most skeptical of their superior qualities for any and all purposes for which plums are used.

MORFMAN.-Medium size and under; deep red, clingstone; season September. Tree rapid in growth, large clean foliage, a regular and heavy bearer. 3 to 5 feet.

WrCOFF.-This plum should be grown commercially for canning purposes, as it makes sauce of unusually fine quality and delicious flavor; its thin skin almost entirely disappears by cooking and possesses none of that bitter or astringent fault in so many other varieties. Tree perfectly hardy in central Iowa and as productive of fruit of above medium size, beautiful light red color and good quality as the most fastidious could desire. We have lately learned the 
true history of this valuable fruit and it proves to be a native of Benton county, Iowa. However, it is not of the Americana type of plums and where the seed could have come from that produced the original tree in the Cedar River bottom is a mystery; it is much the hardiest plum we have in this group. 5 to 7 feet and 4 to 5 feet.

AURORA.-Tree, thrifty, healthy and said to be productive; has not fruited here yet; large, round, bright red, clingstone; season, late. 3 to 5 feet.

BENSoN.- Not fruited here yet; medium to large; deep cherry red, and, like all others of this group, a clingstone; season late; tree thrifty and handsome in form and foliage. 3 to 5 feet.

REFD.-Tree of rubust growth, twigs stocky and clothed with beautiful, large, healthy foliage. Not fruited here yet; said to be above medium size. round, dark, red, late. 3 to 5 feet.

\section{Chickasaw Group.}

Belonging to this family is a long list of varieties of more or less value in certain localities; we will pass them all by but one variety, and this we have found to be very valuable as a pollinator for the varieties of the Wildgoose plum.

NEWMAN.-This past season the fruit was as large as the average Miner and such a load I never saw trees carr y before. Bright red, thin skinned, of excellent quality. Seemingly so hard and glossy while green that it entirely resists the attacks of the curculio; this variety is one of the best pollinators for the Charles Downing. 5 to 7 feet only.

\section{Wild Goose Group.}

This we regard as the commercial group of the native plums. It is safe to say that there are three times as much fruit of this group grown and sold as of all other natives combined. At three cents per quart orchards within fifty miles of a market will yield a handsome profit. The varieties listed in this group can be relied upon to produce easily 15,000 quarts per acre, not every year, but say three out of five. The varieties of this group are not as a rule quite so hardy as varieties of other groups and for that reason would not advise to plant them farther, if quite to the north line of this state.

WHITAKER.-Large, round, oblong, red, clingstone; the earliest good plum in our list; very productive; only a few days later than Milton, which variety is the first to make its appearance on the market. This we have discarded because of its poor quality-and we can afford to wait a few days longer for fruit which will be good when we get it. So for the early plum we advise to plant the Whitaker; it is one of the most profitable orchard varieties, and we consider it the best pollinator in our list for the Charles Downing. 7 to 8 feet and 5 to 7 feet.

DOWNING (CHAS.).-Last season this variety outdid all previous records. This was originated here in Iowa from seed of Wild Goose. Fruit large, round, red, clingstone, of unusual good quality; should be planted alternately with Newman or Whitaker for best results. Its bright cranberry color, thin skin, firm flesh, delicious flavor and its long keeping qualities recommend it to the market grower. 5 to 7 feet and 4 to 5 feet.

Write for anything named in this catalogue. We can supply anything grown by any American nurseryman at reasonable prices.

DUNLAP.-Not fruited here yet; said to be large, round, inclining to oblong; bright red, clingstone; follows after Wild Goose in season; a desirable variety. 4 to 5 feet.

MRS. CIEVIIAND.-Said to be the largest of the group, oblong, red, clingstone; medium season; very fine, not fruited here yet. 3 to 4 feet.

WIID GOOSE.-Large, round, oblong, red; clingstone, early; not so reliable as Whitaker as a crop producer; otherwise there is little difference. 5 to 6 feet.

\section{Tri Flora Group (Japan.)}

The varieties of this numerous family which we consider worthy to be retained in the orchard are very limited. The reason we retain any of them is on account of their superior quality of fruit and great productiveness. In point of hardiness and other characteristics of tree none of them can be very highly recommended. We will continue to propagate a few of the best rarieties which we list below.

BURBANK.-Large, oblong, slightly conical, marbled and orerspread with red, clingstone; season middle to last of August; the most profitable of this group; flesh deep yellow, very sweet, with a peculiar and very agreeable flavor. Price, 5 to 6 feet. $50 \mathrm{c} ; 4$ to 5 feet, $40 \mathrm{c}$.

SWEET BOTAN.-Large, round to slightly oblong, red on vellow, clingstone. When I go to the orchard to get something good to eat I generally begin on these and go the rounds and come back with a few just to top off with. To put it plain they are just simply immense; very productive and young bearer; tree rapid and thrifty grower. This is about as far north as it would be advisable to plant it. Price, 6 to 7 feet, $50 \mathrm{c} ; 5$ to 6 feet, $40 \mathrm{c} ; 4$ to 5 feet, $35 \mathrm{c}$. 
ABUNDANCE.-This very closely resembles the above variety in quality of fruit, also in shape and size, the principal difference being in the color of fruit and some slight variation in tree; if anything the preceding variety is a little hardier in tree. The best way to grow this is to top work it into limbs of some good hardy native, and then you can produce an abundance of most excellent fruit. Price same as Sweet Botan.

BFRCKMANS.-Large, round to slightly oblong; bright red on yellowish ground; cling; ripens with Abundance, and usually is finer in size and color. It is not uniformly as productive as Abundance, yet thinning is necessary where finest fruit is desired. The tree is a free, upright grower, hardy, and a good bearer. 3 to 4 feet.

CHABOT.-This splendid variety has been sent out by various nurserymen under the following names: Bailey, Chase, Furugiya, Hytankyo, Yellow Japan, etc., and its splendid behavior has popularized it everywhere and with everybody who has it fruiting under any name. Large, spherical, inclining to conical: entirely covered with red when fully ripe; cling; ten days to two weeks later than Abundance. Tree hardy, a rapid upright grower and very productive. 3 to 4 feet.

\section{Domestica Group.}

This family embraces the European variety of plums and prunes. Last season's experience with this class of fruit makes one wish for an orchard devoted entirely to such varieties, however such an undertaking would not prove to be profitable unless intelligently managed. They must be sprayed regularly to prevent the curculio from destroying the crop. If it were not for this pest this class of plums, including prunes, could be as easily and profitably produced as any of the common natives, and of late it is in fact a serious question if it will be a profitable undertaking to try to grow the common natives without also preparing to spray regularly. Once we succeed in bringing a crop of these garden plums, as they are sometimes called, to maturity, there is greater satisfaction to be derived from the various uses to which they can be applied than from any other class of plums. Many of them are most delicious dessert fruits, some are unexcelled for culinary use and several make excellent prunes when properly cured. Te submit a short list of the best of this class for this section.

RICHIAND.-Tree upright, vigorous and hardy; fruit prune shaped, with very marked suture, medium to large; covered with a heavy bloom underneath, which is a coppery color, tinged with blue; flesh greenish yellow; juicy, sugary, and freestone; very heavy bearer. A very fine fruit for dessert or culinary use and makes an excellent prune when cured. 5 to 7 feet, 4 to 5 feet and 3 to 4 feet.

MIRABEIIE. - This variety was introduced from Warsaw in Poland. A slow growing, hardy, round-topped tree, clean and healthy; fruit of light golden yellow color and small size borne in great profusion; freestone and very smal? pit; for home use thers is not a better plum to be found; they are just simply delicious and so sweet they require but a very small amount of sugar and will make a very good sauce without any. Price, 4 to 5 feet, $40 \mathrm{c} ; 3$ to 4 feet, $35 \mathrm{c}$; 2 to 3 feet, $30 \mathrm{c}$.

COMmUNIA.- Introduced by the Communia Colony, of northeast Iowa. A fine grower, with large, perfect foliage and is an early and continuous bearer of quite large, blue fruit with much bloom; a fine fruit for culinary use or dessert; should be in every garden. 5 to 7 feet, 4 to 5 feet and 3 to 4 feet.

SPANISH KING.-Tree very vigorous and hardy, a young and heavy bearer. Flesh deep yellow, juicy, pleasant and sweet. Ripens middle of August. This plum makes an excellent prune when properly cured. 5 to 7 feet, 4 to 5 feet and 3 to 4 feet.

TAGE.-A seedling originated at Belle Plaine, Iowa, some twenty-five years ago; "bears the name of its originator; has stood all the test winters unharmed. It is a fine grower, an early and profuse bearer; fruit large, dark blue, of splendid quality; makes a fine prune, properly cured. 5 to 7 feet and 4 to 5 feet.

BIUE MOIDOVKA.-Here is a fruit which has been a great delight to me this season. I do love to eat those great big, luscious, melting fellows; freestone, large blue, with slight suture; imported from Russia; perfectly hardy, very desirable. 4 to 5 feet, 3 to 4 feet and 2 to 3 feet.

BROWN SFEDIING.-Originated in Louisa county, Iowa; of the Domestic type; it is claimed to have borne 75 per cent. of a crop when the natives were all destroyed; the original tree is about 20 years old, has borne regularly, fruit larger than Lombard, dark purple, and has never been known to rot upon the tree. Mr. Silas Wilson once said this was the finest plum he ever saw. One year buds; 3 to 5 feet, $25 \mathrm{c}$ each.

GIRIMAN PRUNE.-This is one of the best of the prune family, of fine quality for dessert use, and especially esteemed for drying and preserving: abundant bearer; flesh firm, sweet and pleasant; freestone. Tree not so hardy as other varieties of this group, and should not be planted much north of here. 5 to 6 feet only.

DAMSON (BIUE).-This is the little old fashioned Blue Damson; some way people, from the east, especially, won't forget this little thing; they make good pies and they are prolific and have done well in this section for a long time; not strictly hardy, but people will have it anyway. 5 to 6 feet and 4 to 5 feet. 
GIANT PRUNE.-A fine large fruit which has been very productive in my orchard, and is moderately hardy. 4 to 5 feet and 3 to 4 feet.

\section{Hybrid Group.}

Of these our list is short, but promises to be very interesting in the future and we hope profitable. Out of the many hybrids making their appearance at the present time we have to believe something will evolve which will prove to be a great boon to the fruit grower.

COMPASS CHERRY.-A hybrid of Miner plum and Sand cherry. A wonderfully healthy, thrifty tree; bears profusely at two years old; fruit small, of a dingy red color, quality fine for culinary use; very hardy and interesting. 3 to 4 feet, $25 \mathrm{c}$ each.

GONZALES PIUM.-Parentage unknown; has some of the ear marks of both the Japans and Chickasaws. This fruited in this county the past season and is very promising for trial. It is very highly praised in other sections of the country. Fruit large to very large, nearly round, bright red, with very small seed; clingstone; medium season; very productive. 4 to 5 feet, 3 to 4 feet and 2 to 3 feet.

Here is just the thing to start a commercial plum orchard with and only a small outlay of cash is required. The following is a list of one year plum buds and root grafts, b, designates buds and $r-g$, root grafts. We will make up collections of 100 for $\$ 10.00$; lesser quantities at prices as per list.

America, 1 to 2 feet, $\mathrm{r}-\mathrm{g}, 10 \mathrm{c}$; Ames, 1 to 2 feet, $10 \mathrm{c}$; Aurora, 1 to 2 feet, $\mathrm{r}-\mathrm{g}, 10 \mathrm{c}$; Beatty, 2 to 5 feet, $\mathrm{b}$ and $\mathrm{r}-\mathrm{g}, 15 \mathrm{c}$; Benedict, 1 to 3 feet, $\mathrm{r}-\mathrm{g}, 10 \mathrm{c}$; Benson, 2 to 4 feet, r-g, 10c; Berckmans, 2 to 4 feet, 10c; Black Hawk, 1 foot, r-g, $10 \mathrm{c}$; Blue Moldovka, 2 to 5 feet, b, 15c; Brittlewood, No. 1, 1 to 2 feet, r-g, 12c; Brown Seedling, 2 to 5 feet, b, 25c; Champion, 1 to 2 feet, r-g, $10 \mathrm{c}$; Climax, 1 to 3 feet, r-g, 10c; Dunlap, 1 to 2 feet, r-g, 10c; English Seedling, 2 to 5 feet, b, $15 \mathrm{c}$; Forest Rose, 1 to 3 feet, r-g, 10c; Gold, 1 to 3 feet, $r-g, 15 \mathrm{c}$; Golden Queen, 1 to 2 feet, r-g, 10c; Gonzales, 2 to 3 feet, r-g, 12c; Goosedye, 1 to 3 feet, r-g, $15 \mathrm{c}$; Hunt, 1 to 2 feet, $\mathrm{r}-\mathrm{g}$ and $\mathrm{b}, 10 \mathrm{c}$; Kneble, 3 to 5 feet, b, $12 \mathrm{c}$; Mankato, 1 foot, r-g, 10c; Micado, 2 to 4 feet, r-g, 10c; Mrs. Cleveland, 2 to 3 feet, r-g, 10c; Moreman, 1 to 5 feet, $\mathrm{r}-\mathrm{g}$ and b, 10c; Nellie Blanche, 1 to 2 feet, $\mathrm{r}-\mathrm{g}, 10 \mathrm{c}$; Odegard, 1 foot, $\mathrm{r}-\mathrm{g}, 10 \mathrm{c}$; Omega, 1 to 3 feet, $\mathrm{r}-\mathrm{g}, 10 \mathrm{c}$; Oren, 1 foot, $\mathrm{r}-\mathrm{g}, 10$; Prairie Flower, 2 to 4 feet, r-g, 10c; Prof. Budd, 2 to 3 feet, r-g, $12 \mathrm{c}$; Reed, 2 to 3 feet, r-g, 10c; Richey, No. 1, 1 to 2 feet, 10c; Rowe, 1 to 3 feet, $r-g$ and $b, 10 \mathrm{c}$; Shiro, 1 to 3 feet, $r-g, 10 c$; Surprise, 1 foot, $r-g, 15 c$; The Cook's Choice, 1 to 2 feet, $r-g$. $10 \mathrm{c}$; U. S. (Brittlewood No. 2), 1 to 2 feet, $15 \mathrm{c}$; Waugh, 2 to 4 feet, r-g, 25c; Whitaker, 2 to 3 feet, r-g, 10c; Wyant, 1 to 2 feet, r-g, 10c; Wycoff, 2 to 4 feet, $\mathrm{r}-\mathrm{g}, 12 \mathrm{c}$

Remember that first-class stock always commands first-class prices. Do not be deluded into the thought that some one is going to furnish first-class stock at second-class prices. In buying anything it always pays to buy the best and this is specially true when it comes to nursery stock.

\section{Select Cherries.}

Of recent years this fruit has been in greater demand than any other line of fruit and will continue to be so for years to come, and those engaged in fruit growing on favorable soils will do well to plant liberally of this fruit. Cherry trees are, as a rule, short lived. They actually bear themselves to death. We have some old Early Richmond trees in our orchard which have not failed to produce a full crop in the last ten vears. We cannot, in reason, expect them to keep this up much longer. Cherries will thrive on any good, well drained upland. We have an unusually large stock of the leading varieties of cherry, mostly two years old, and in all grades and sizes up to six and seven feet, mostly budded on the mahaleb stock; they are of thrifty growth and smooth. We have quite a number of new varieties on trial and in due time doubtless will have something good to offer. The following described varieties we have found to be the best, out of a long list we have had experience with.

\section{Price I, ist of Cherry Trees, Except as Noted Otherwise.}

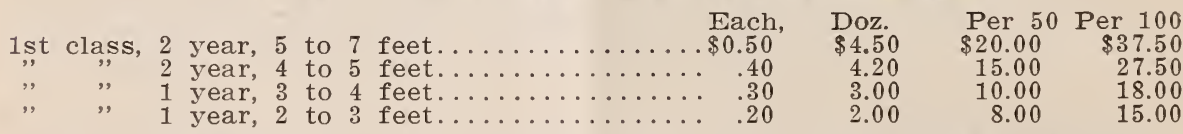

Six at dozen, 25 at 50 and 50 at 100 rates; the above rates to apply only when the quantity taken is of one variety; six of a variety at dozen rates, and lesser quantities at piece rates; orders for 25 or 50 trees containing a long list of varieties cannot be filled at 50 and 100 rates.

FARIY RICFMOND.-The earliest cherry we have yet fruited; ripens latter part of June. Color red, quality acid, valuable for cooking early in season. Tree hardy and a regular bearer. 5 to 7 feet, 4 to 5 feet, 3 to 4 feet, and 2 to 3 feet. 
MONTMORENCY.-Tree very hardy, immensely productive. fruit very large, flesh firm and meaty, much superior to Richmond for canning; the most profitable cherry to plant for market; has borne eight full crops in succession here in our orchard. Color bright, clear red, two weeks later than Richmond. 5 to 7 feet, 4 to 5 feet, 3 to 4 feet, and 2 to 3 feet.

WRAGG.-This is a sturdy grower and an immense bearer of large, handsome, dark colored fruit, which ripens early in July. A fine, healthy, hardy tree. 5 to 7 feet and 4 to 5 feet only.

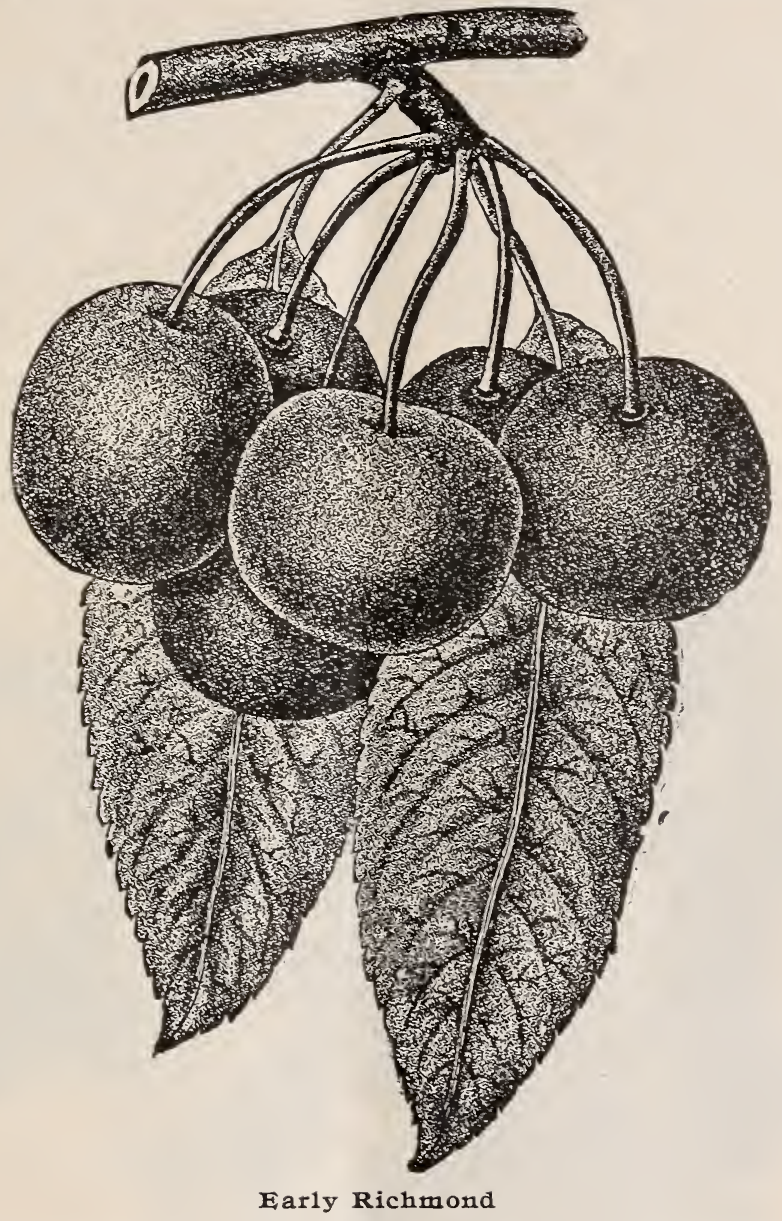

OSTHEIM.-A hardy cherry, imported from Russia. It has been tested extensively i nthe Mississippi valley and has proven to be perfectly hardy. Fruit large, roundish, obovate. Flesh liver color, tender, juicy, mild, sub-acid, almost sweet, very good. The king of all good cherries of the Morello class. 5 to 7 feet only.

INGIISH MOREIIO.-Medium to large; blackish red; rich, acid, juicy, and good, one of the best in our list; very productive. Tree a moderate grower; season, July. 5 to 7 feet, 4 to 5 feet only.

DOUBLE GIASS.-We received this variety from Prof. Budd, of Ames. This past season we sent him a package of the fruit from our trees and here is his reply: "The variety sent is Double Glass. It is as large as the Yellow Spanish of California and the south, heart-shaped, bright vellow in color and sweet. It was found by the writer in 1882 in North Silesia and imported under the name of Doppelte glebe glasskirrche. The name comes from the large yellow fruits grown in pairs and often in triplets. It is fully as hardy at Ames as the Early Richmond, and indeed, hardier, as we have trees in Ames 15 years old and there is not an Early Richmond of that age left." 1 year buds, 5 to 7 feet, $35 \mathrm{c}$.

Beautify your Home; Increase your Profits; Plant Snyder's Trees.

A Dollar in time will make Nine, if you invest it in Snyder's Nursery Stock. You take no chances when you plant BIACK ANNETTE Apple Trees. 


\section{Select Grapes.}

The grape is one of the most highly prized, as well as one of the most healthful of fruits, and it is adapted in some of its varieties to nearly all portions of the country and with a little care and attention can be raised on every farm and in every garden. It can be grown by any one who has a garden, a yard, or a wall; can be confined to a stake, tied to a trellis, trained over an arbor or allowed to corer a tree or building. Generally the vines do best trained on a trellis, and where the winters are severe, they should be pruned in the fall, laid down and covered with soil. The grape should be planted on well-drained land. They will not thrive over a cold, wet and stiff subsoil. Prepare the land in which to set grapes by plowing and subsoiling just as deep as the tools can be run. Then dig big holes in which the roots can be spread out without crossing or doubling them up. Any good, ordinary farm land will produce fine grapes in Iowa. Eight feet apart each way is a very good distance to set them; six by eight will do, but more is better. Cut back to two buds the first rear and rub off all others as they appear. The first autumn, cut back to four or six buds and cover the vine with earth. Let two canes grow the second year and in autumn cut one of them back to three buds and the other to the length of about four feet to bear. This severe pruning gives them a strong root before allowing them to bear. Give them thorough, clean surface cultivation and you will be richly rewarded.

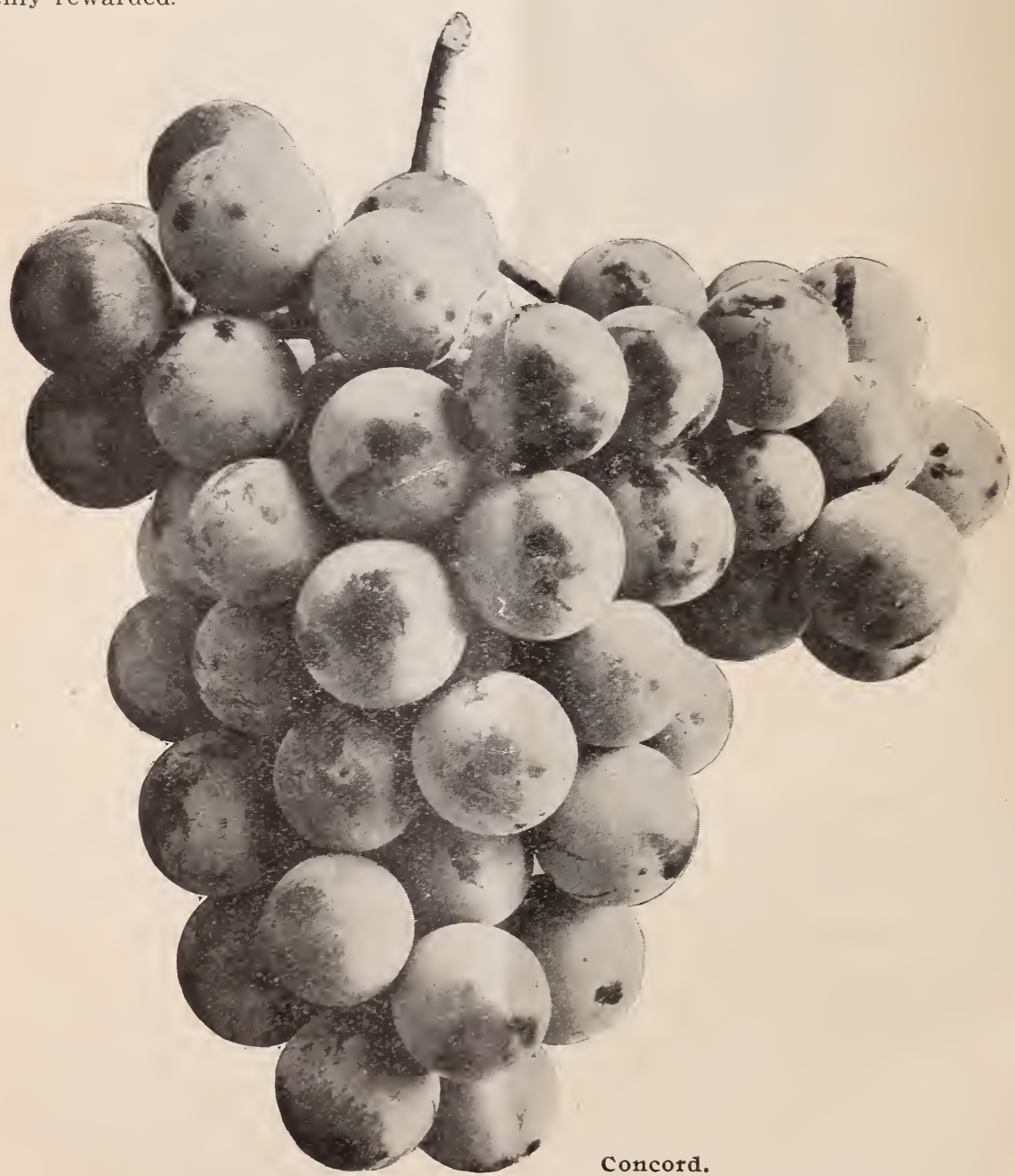

CONCORD.-Black. - This has been for many years the grape for general planting. Bunch and berry large. Medium early. Vine very hardy and healthy. $10 \mathrm{c}$ each; $90 \mathrm{c}$ per dozen; $\$ 7.00$ per i00, 2 year No. 1. 



\section{ERRATA:}

The following list of standard grapes was by error omitted from the body of the catalog. We have a good stock of these well known varieties:

DELAWARE.-A noble variety, in quality most exquisite; does well here if given a little winter protection. Bunch and berry quite small, but of most heautiful compact form. Color light red, very sweet, juicy and highly flavored. Wis is considered one of the best, if not the best American grape. 10c each; $\$ 1.00$ per dozen, 2 year No. 1 .

MOORI'S FARIY.-Black and very valuable. Two to three weeks earlier than Concord. Bunch medium. Berries larger than Concord. Should be in every garden. $12 \mathrm{r} / 2 \mathrm{c}$ each; $\$ 1.25$ per dozen; $\$ 10.00$ per 100,2 year No. 1 .

MOORE'S DIAMOND.-This new grape has evidently come to stay. Color. white; berries large with whitish bloom; skin thin; flesh melting, juicy and sweet to the center. Vine a strong grower and abundant bearer, healthy and very hardy. $10 \mathrm{c}$ each; $\$ 1,00$ per dozen; $\$ \$ .00$ per 100,2 year, No. 1 .

WORDEN.-The best of all black grapes and the most productive and satisfactory of all varieties. A strong grower, heavy yielder, healthy foliage, fine showy bunches and large berries of excellent quality, ripening early. It should be the first to be selected in making a garden collection. $10 \mathrm{c}$ each; $\$ 1.00$ per dozen; $\$ 7.50$ per 100 .

WYOMIITG RED.-One of the earliest red grapes. Bunch and berry rather small. Vine healthy, hardy and moderately vigorous. Very productive, sweet and desirable. Price of six varieties above 2 year, No. $1,10 \mathrm{c}$ each: $\$ 1.00$ per dozen; $\$ 8.00$ per 100 .

WOODRUFF RED.-Very large and handsome. Color, red; strong grower, very healthy and hardy. Pronounced delicious by good judges. A few days later than Concord. 2 year. No. $1,25 \mathrm{c}$ each; $\$ 2.75$ per dozen; $\$ 16.00$ per 100 .

CAMPBEII'S FARIY.-This much lauded grape does not adapt itself to the conditions prevailing in our vinevard; such varieties as Moore's Early, iTorden and Concord occupying rows

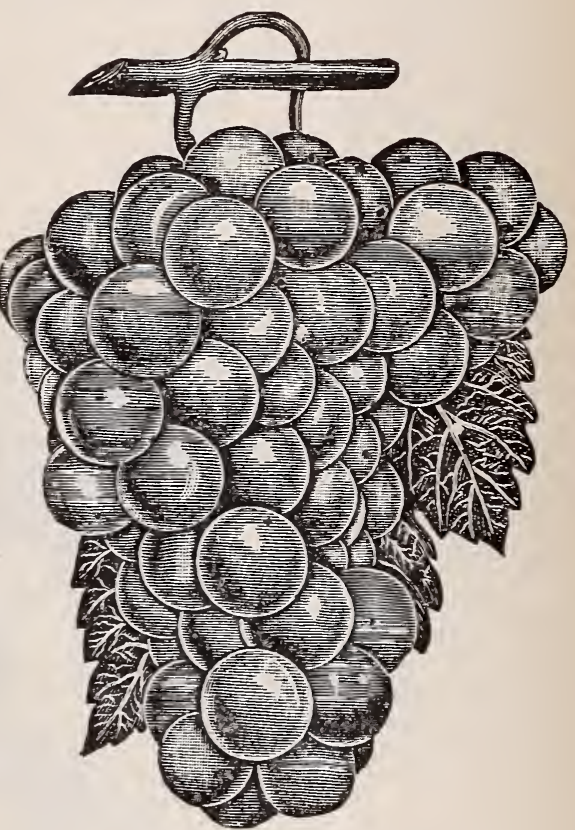

Moore's Diamond. alongside of it, receiving the same care, are more than one hundred times more profitable; in fact, it has not (and is making strong promises not to do so) yet paid the original cost of the vines. 2 year No. 1, 25c each; $\$ 2.75$ per doz.

MC PIKE.-A seedling of the Worden, fully as vigorous, hardy and productive, ripening at same time. Bunch very large, compact, black with blue bloom: berries mammoth size, usually three inches or more in circumference, extra fine quality. Has now been well tested in nearly all grape growing sections and easily takes first rank as the very best large grape, rivaling Black Hamburg in size and quality; as easily grown as Concord or Worden. Our advice is to go slow on this variety also, as it bids fair to little if any better than Campbell's Early. 2 year No. 1, 75c each; $\$ 8.00$ per dozen.

\section{S. W. SNYDER,}


AGAWAM.-Fine, large, red, borne in clusters of good size, excellent quality, aromatic flavor, peculiar to this variety. Strong growing vine and very productive. Should have winter protection in this locality. 10c each; $\$ 1.00$ per dozen; $\$ 8.00$ per 100,2 year No. 1 .

BRIGHTON.-Dark Red.-One of the most desirable of the early red grapes. Should be planted near other varieties, as its blossoms do not always fertilize when alone. This variety should have winter protection. $10 \mathrm{c}$ each; $\$ 1.00$ per dozen; $\$ 8.00$ per 100,2 Jear No. 1

FIVIRA.-Pale Green, late.-Very vigorous and extremely productive. Bunch and berry medium and very compact. One of the best white wine grapes. $10 \mathrm{c}$ each; $\$ 1.00$ per dozen; $\$ 8.00$ per 100,2 year No. 1 .

POCKIIMTON. - white, very large and showy.-Vine very hardy and vigorous, Bunch and berry large. Ripens about with Concord and is better in quality. $10 \mathrm{c}$ each; $\$ 1.00$ per dozen; $\$ 8.00$ per 100,2 year No. 1 .

NIAGARA.- White.-Quality about like (and ripens soon after) Concord. $\$ 1.00$ per dozen; $\$ 8.00$ per 100,2 year No. 1 .

$\$ 1.00$ per dozen; $\$ 8.00$ uer 100,2 year No. 1.

\section{Select Currants.}

Currants should be planted in good, very fertile soil, with liberal manuring, and the tops should be cut back nearly to the crown, allowing only three or four canes to grow the first year. Plant in rows five or six feet apart and three feet in the row. Prune more or less every year to get rid of the old wood and keep the bushes open. Currant worms should be vigilantly looked for in spring and summer. These worms can be destroyed by white hellebore, one ounce to three gallons of water, and apply with a sprinkling can. Be s ire and use the remedy as soon as or before the worms appear. The currant is well adapted to our soil and climate and every one should have a liberal supply. Also see spraying bulletin, page - , for additional remedies to destroy the currant worm.

WIIDFR.-A remarkable variety, for which we predict great popularity, both

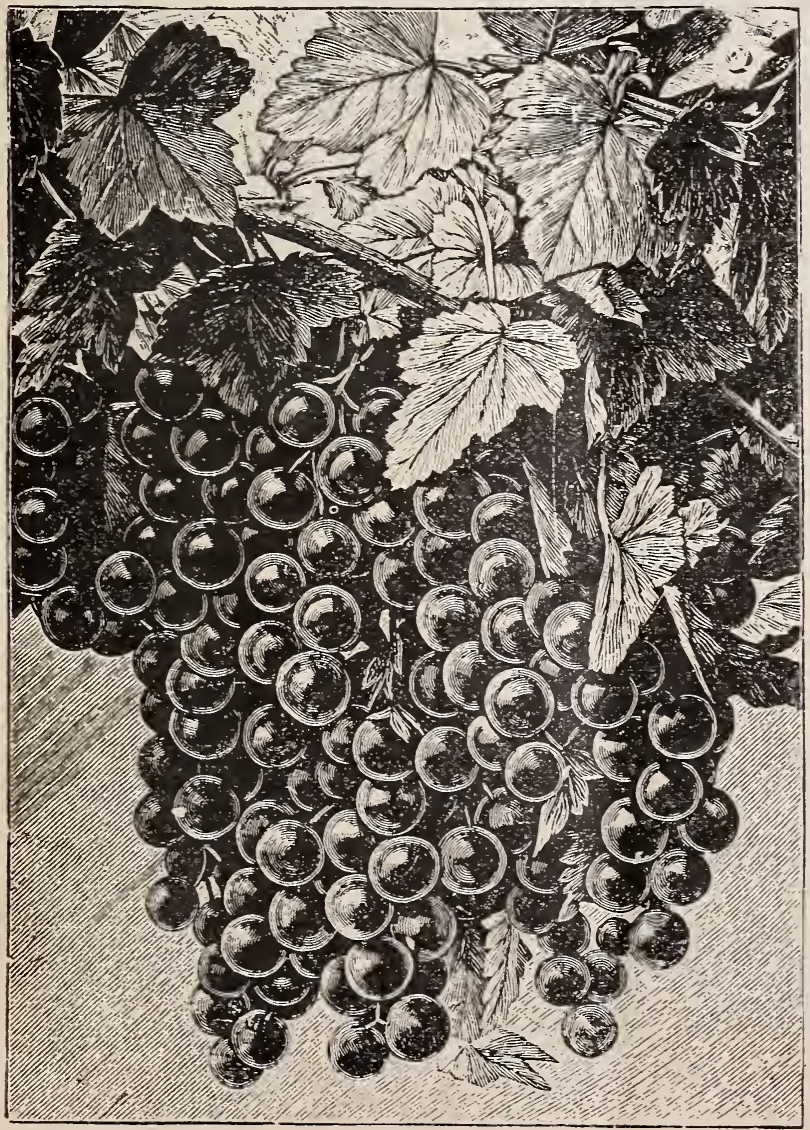

Wilder.

for table and market. One of the strongest growers and most productive. Bunch and berries very large, bright, attractive red color, even when dead ripe; hangs on bushes in fine condition for handling as late as any known variety. Compared with the celebrated Fays, is equal in size, with longer bunch, better in quality, with much less acidity; ripens at same time, continues on bush much longer; fully as prolific, in some trials largely outyielding it. Recommended by our Experimental Station as the best red currant. Price, 2 year, No. 1, 15c each; $\$ 1.50$ per dozen.

VICTORIA. - This is a standard, very good and reliable currant, and will suit everybody. Very large, bright red; bunch is very long, very productive. 10c each; $\$ 1.00$ per dozen.

CFrrRY. - Strong grower; fruit very large. sometimes measuring one-half inch in diameter. Should have good soil and thorough cultivation. $10 \mathrm{c}$ each; $\$ 1.00$ per dozen.

VIRSAIIIES. - A currant of great beauty, as bunches are long and berries of large size and excellent quality. $10 \mathrm{c}$ each; $\$ 1.00$ per dozen.

For want of space we only name other red cur. rants we have, viz.: Wilder, Prince Albert, North Star, Fay's Prolific. and Red Dutch. Price, $10 \mathrm{c}$ each; $\$ 1.00$ per dozen. 
POMONA CURRANT.-A new variety of red currant, as reported by all experiment stations having it on trial; it outyields all others. $15 \mathrm{c}$ each; $\$ 1.50$ per dozen.

RED CROSS CURRANT.-A new variety, said to be later than most other sorts, claimed to be double the size of Tictoria and very prolific. Same price as Pomona.

WHITE GRAPE.This is justly becoming very popular; very large, white. The very best currant known to us, sweet or very mild acid, good grower and hardy. Has been very satisfactory, and is a currant we can recommend for any purpose. Price, $15 \mathrm{c}$ each; $\$ 1.50$ per dozen.

WHITE TRANSPARENT CURRANT.-Has taken first prize eleven times in fourteen years, for the best white currant at annual exhibitions of Massachusetts Horticultural Society. It has a delicate flavor, milder than White Grape. Plant thrifty, healthy, upright grower; perfectly at home in Iowa soil. Price, same as White Grape.

\section{Gooseberries.}

As to soil, cultivation, etc., all we have said concerning the currant applies to the gooseberry. Who, that is acquainted with its different uses and knows the delights of a good gooseberry pie, would ever again willingly be without this most healthful of fruits?

HOUGHTON.-Medium size, pale red, quite sweet and enormously productive. This we regard as our standby. Has the genuine gooseberry flavor. $10 \mathrm{c}$ each; $\$ 1.00$ per dozen; $\$ 8.00$ per 100.

DOWNING.-Fruit nearly twice as large as Houghton. Flesh whitish green, soft, juicy and good. Lacks the genuine gooseberry flavor of the above. Plant vigorous; one of the best. Price, 2 year, No. 1, 10c each; $\$ 1.00$ per dozen; $\$ 9.00$ per 100 .

CHAMPION.-About as large as Downing; enormously productive; never known to mildew; one of the very best sorts for home use or market. "I never saw a gooseberry that will compare with the Champion one year with another, and all things considered."-Prof. J. L. Budd, Iowa Horticultural Report, 1897. 2 year, medium, $15 \mathrm{c}$ each; $\$ 1.50$ per dozen; $\$ 10.00$ per 100 .

JOSSEIYN-(Red Jacket.)-A new berry which is likely soon to take first place, as large as the largest, berry smooth, very hardy and prolific; has recently been re-named in honor of its introducer, Mr. Josselyn. Price, 2 year, No. $1,15 \mathrm{c}$ each; $\$ 1.50$ per dozen; $\$ 10.00$ per 100 .

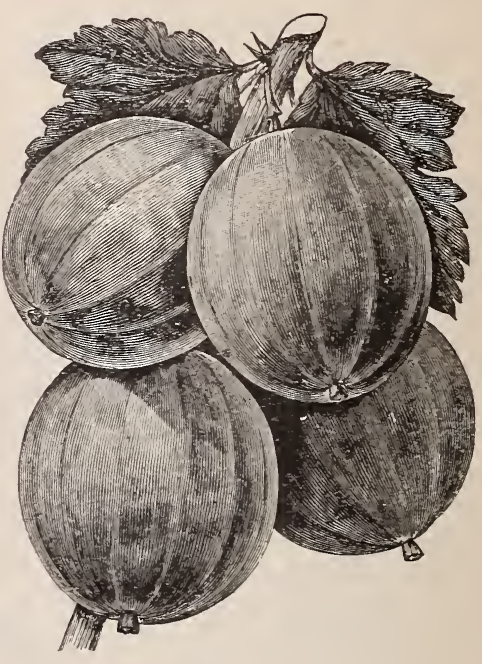

Champion.

\section{Select Raspberries.}

The plan most commonly recommended for laying out the raspberry plantation is to plant in rows from six to eight feet apart and two to three or more feet in the row; but recent experience has convinced us that there is a much better plan; we now plant raspberries in hedge rows; plant one foot apart in row and rows twelve feet apart. The dense hedge row smothers out all weeds in and near the row, rendering cultivation easier and quicker; keep this space between the rows well and frequently cultivated. It is a well known fact that raspberries are always larger, finer and sweeter if grown partially in the shade; the hedge row furnishes this condition. It also stays the young canes against the wind twisting and breaking them, resulting in more and better canes, more and finer fruit, and rendering easier and quicker cultivation. Give this plan a trial and you will soon be convinced of its advantages over the old way.

OIDER.-This we consider well worthy to head the list, the greatest drouth

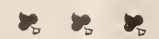

Do you want fine ornamental trees to plant for shade? We recommend European White Birch, Oak Ieaved Mountain Ash, Camperdown Weeping Elm, Cut Ieaved Weeping White Birch, Tea's Weeping Mulberry, Iinden and Sugar Maple. 
resister among raspberries. Is among the earliest and is the largest black cap we have any knowledge of. Ripens all its fruits perfectly. Last berries as large as the first. Has small seeds with much pulp and rich juice, therefore the most healthful of all raspberries. People who would not dare to use the dry, seedy varieties can use these freely. Originated in Iowa and is of iron clad hardiness. $40 \mathrm{c}$ per dozen; $\$ 2.00$ per $100 ; \$ 12.00$ per 1,000 .

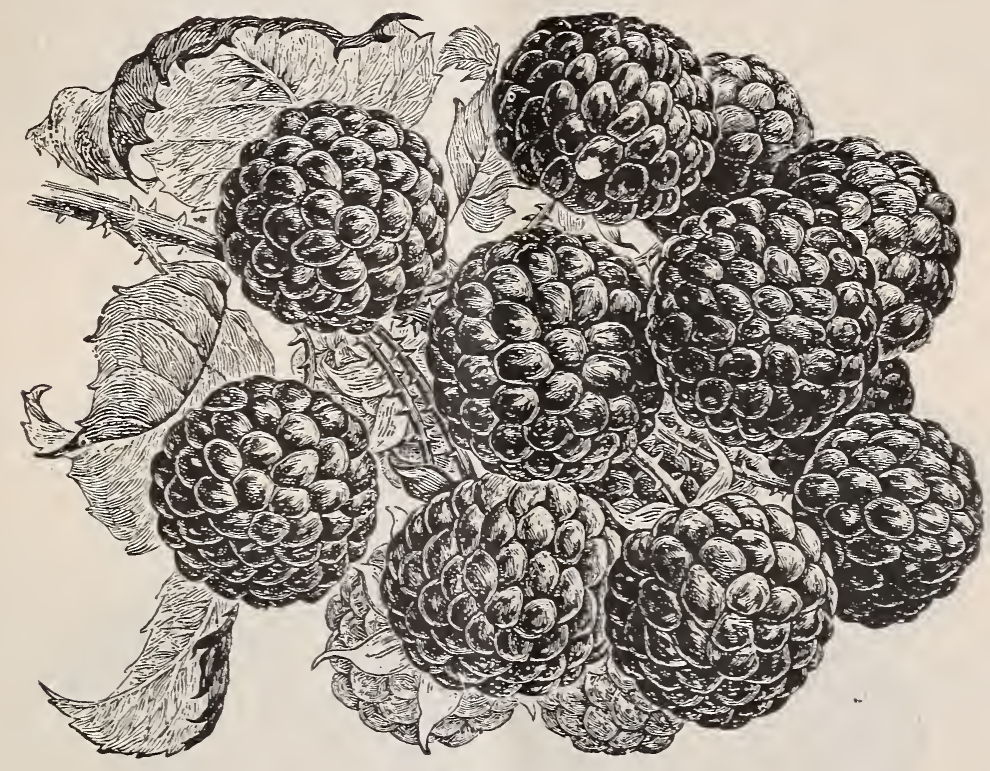

Kansas.

KANSAS.-A large, early berry, is very large and fine. Many experiment stations have placed it at the head of the list. A very strong grower; withstands drouth splendidly and is enormously productive. Same price as older.

GREGG.-Of great size, fine quality, very productive; has been a standby and very popular for years; several days later than Older or Kansas. No one can afford to be without it. Same price as Older.

NFMPFA.-A seedling of Gregg and the fruit seems to be identical. Supposed to be hardier in cane than its parent. Same price as Older.

CONRATH.-At present this holds the place for best midseason black cap. It is of iron-clad hardiness, berries large, shiny black and always good sellers. Enormously productive and a good shipper. Price, 50c per dozen; $\$ 2.50$ per 100 ; $\$ 15.00$ per 1,000 .

FURFrA.-Ripens nearly with Palmer; fruit firm, of large size, equaling Gregg; superior quality; free from bloom, making it very attractive in fruit box; brings the highest market price. Strong grower, very hardy, healthy foliage, and in some localities stands at the head for productiveness. Produced an unusually fine crop this past season. Price, $50 \mathrm{c}$ per dozen; $\$ 2.50$ per $100 ; \$ 15.00$ per 1,000 .

MUNGIR.-The fruit of Munger is black, and resembles Gregg very much. It is a better flavored berry than Gregg, tougher in texture, and therefore a better shipper. In size it excels Gregg by almost 25 per cent., being extra fine for canning and evaporating. The canes, too, resemble Gregg, but stand extreme cold very much better; free from disease, upright in growth. Price, 50c per dozen; $\$ 2.50$ per $100 ; \$ 15.00$ per 1,000 .

CUMBERIAND.-This new berry is a very valuable acquisition. Its hardiness has been proven and will thrive anywhere that blackcaps can be grown. The quality is very similar and fully equal to Gregg. In spite of its unusual large size, the fruit is possessed of great firmness and is thus well adapted for standing long shipments. It follows Palmer and Souhegan and precedes Gregg a short time, making it a midseason variety. The bush is exceedingly healthy and vigorous, throwing up stout canes, well adapted for supporting their loads of large fruit. Price, $75 \mathrm{c}$ per dozen; $\$ 3.00$ per 100.

An Orchard well tilled, a pocketbook well filled. 


\section{Purple Cap Varieties.}

THE NEW CARDINAT RASPBERRY.-This wonderful berry is a surprise in the fullness of its merits-its great growth, extreme hardiness and the exceeding productiveness of its choice, red, rich, pure flavored berries. It will pay. It is not a novelty, but a variety of great merit. The new Cardinal is claimed to grow ten feet high and bears in proportion. Leading horticulturists who have seen this berry say it is one of the wonders of the century, so far exceeding all others as to put it berond comparison." Judge Wellhouse, president of Kansas State Horticultural Society, said at the meeting of the society that the introduction of the Cardinal raspberr would add millions to the wealth of the farmers of the country because of its inherent great vigor and exceeding productiveness. Four years' trial on our grounds has verified every claim in the above description. Price, $10 \mathrm{c}$ each; $\$ 1.00$ per dozen; $\$ 7.50$ per 100 .

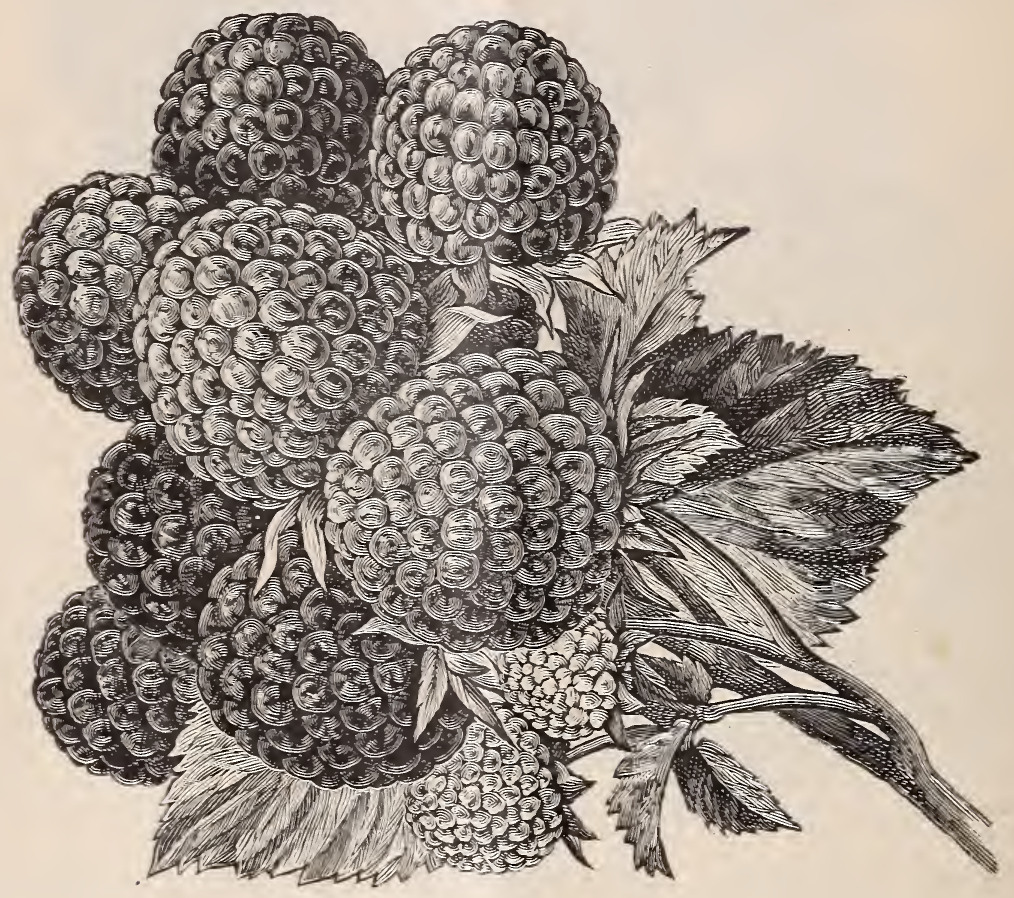

Cardinal.

HAYMAKER.-An Ohio seedling of the Shaffer and Columbian type; fruit a little more acid and is later than either, prolonging the season. An enormous producer excelling the Columbian. It is very much superior to shaffer or Columbian; not so dark colored and is firmer than either of these varieties; does crumble; stands up well in shipping; quality good, either for table or canning; produces very large crops; stands drouth or extreme cold splendidly; a close second to the Cardinal; a little larger berry, but not quite as good in cane or foliage; plants same price as Cardinal.

Red and Yellow Varieties.-These are multiplied by suckers; they sprout all over the ground near them and must be confined to narrow rows by running the plow through frequently during the growing season; properly managed they excel all other raspberries for quality and equal them in productiveness; for my part I could not think of discarding them.

TrE MIIIER.-This is now the most generally planted of the early red raspberries. It proves hardy and productive. The berries are very firm, large, bright red and good. Price, $25 \mathrm{c}$ per dozen; $\$ 1.50$ per 100 .

CUTHBERT, or QUEEN OF THE MARKFT-A remarkably strong, hardy variety. Stands the northern winters and southern summers equal to any. Berries very large, measuring three inches around; conical, rich crimson, very handsome, and so firm they can be shipped hundreds of miles by rail in good condition; flavor is sweet. rich and luscious. The leading market variety for main crop. Price, $25 \mathrm{c}$ per dozen; $\$ 1.50$ per 100 . 
THE FARIY KING.-Very vigorous in cane and will surely take the first place as an extra early large red berry. Its hardiness and earliness have been fully tested during the past winter when not a bud was injured. Price, $75 \mathrm{c}$ per dozen; $\$ 3.00$ per 100 .

IOUDON.-The superior points of this excellent red raspberry are vigor of growth, large fruit, beautiful rich dark crimson color, good quality and great productiveness and hardiness, enduring our coldest winters without protection. Price, $40 \mathrm{c}$ per dozen; $\$ 2.00$ per 100.

IOWA.-This new raspberry is a great favorite in the north and northwest part of this state; it is a dwarf in growth, making canes about 2 to 3 or $3 \frac{1}{2}$ feet. The fruit is very large and continues for a remarkably long season, beginning to ripen soon after July 4 th and usually extending to the middle of August; makes but few suckers and is easily kept in rows; stands drouth remarkably well, and is not affected by anthracnose; has proved hardier than other raspberries, either black or red. Price, $75 \mathrm{c}$ per dozen; $\$ 3.00$ per 100 .

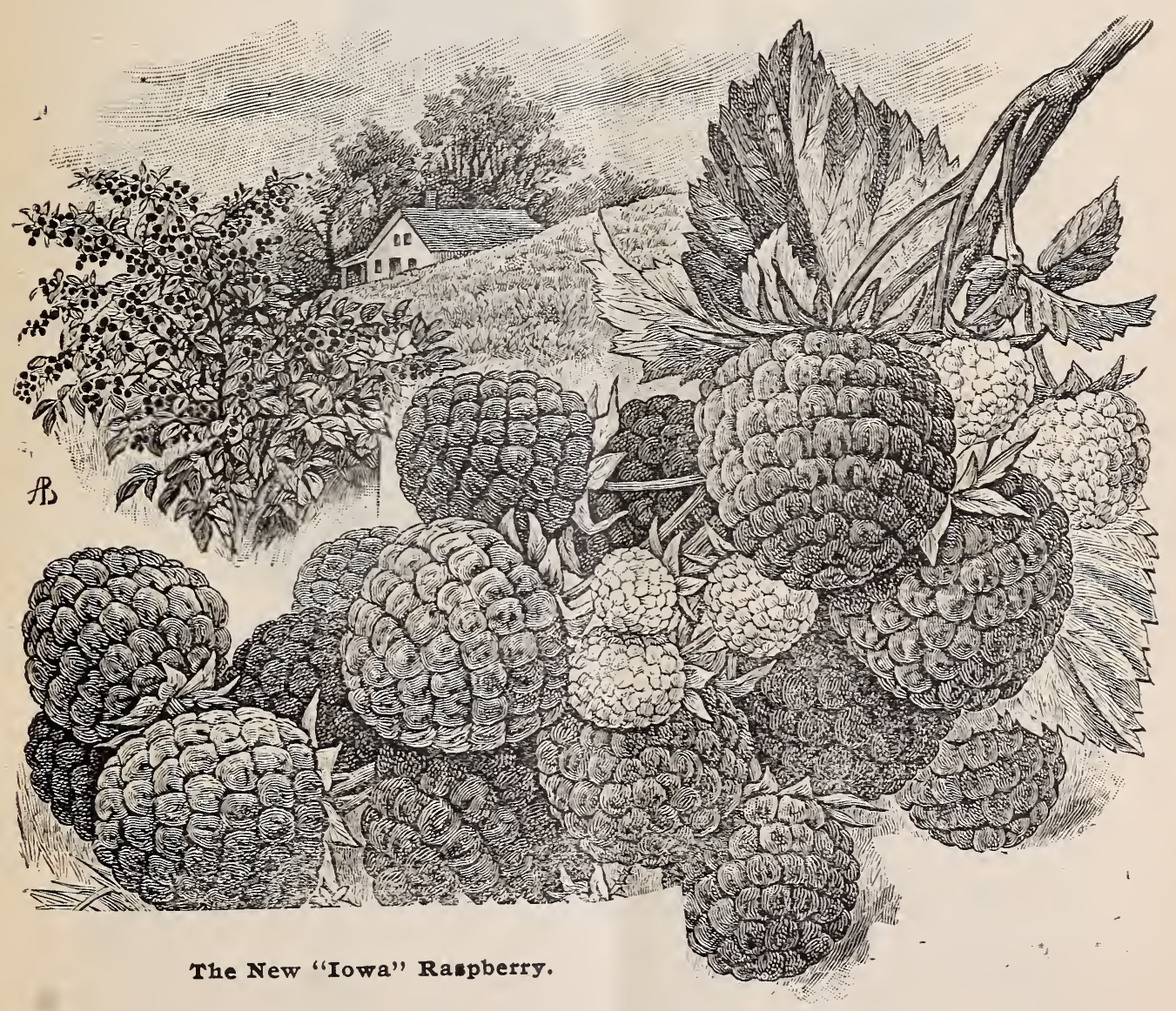




\section{Select Blackberries.}

About the same general directions will apply as for the raspberry. Our plants are of regular nursery propagation; root cutting plants are worth tenfold more to the fruit grower than sucker plants dug from old exhausted patches, this latter being the cause of most of the failures in attempts to produce this valuable fruit; be sure that you will get genuine nursery propagated plants and you will succeed. The blackberry is naturally a stronger bush than the raspberry and should be planted in rows eight feet apart and three feet in the row. Otherwise their culture is the same as raspberries.

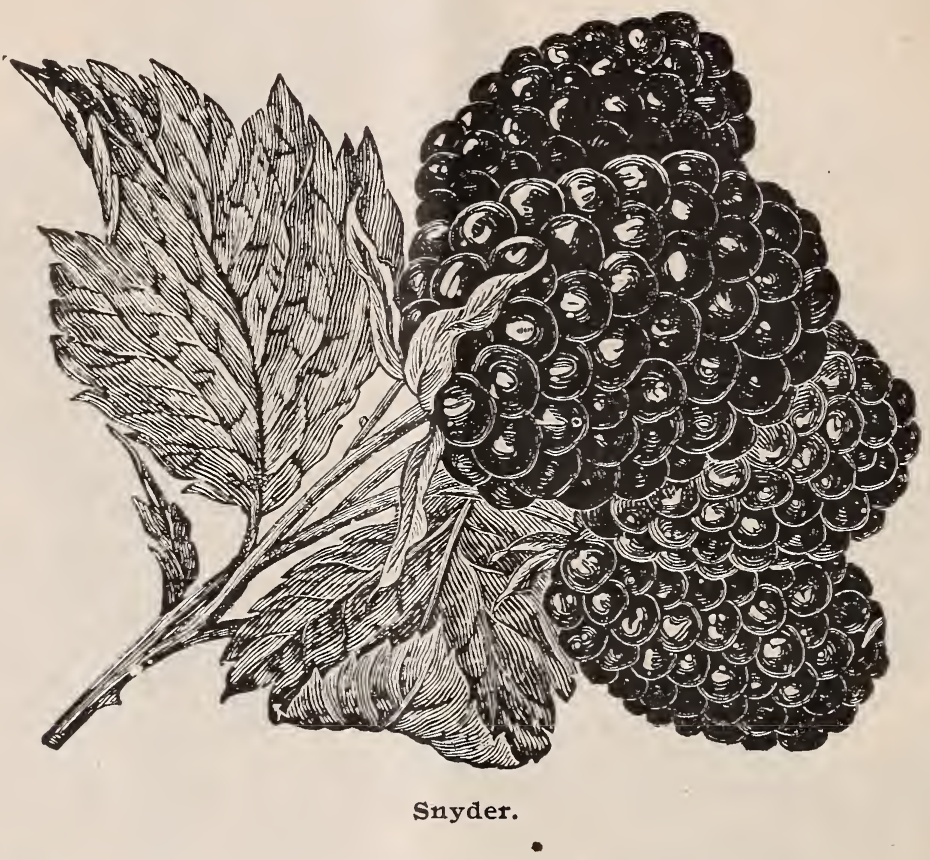

SNYDER.-This is the old stand-by which succeeds anywhere a blackberry can be grown. If properly pruned and cared for is good enough for anybody. Price, 50c per dozen; $\$ 2.50$ per $100 ; \$ 10.00$ per 1,000 .

AGAWAM.-Ranks highest in quality. Prof. Bailey pronounces it as the best and it is probably the most popular berry in New York, where it originated. It has been proven to be entirely hardy and especially valuable for family use where quality is the first consideration. Same price as snyder.

ANCIENT BRITON.-The leading berry in the northwest, where it grows to great perfection. Its canes and flexible roots render it easy to lay down for winter protection. Its berries are fine; season medium early. Same price as Snyder.

OHMER.-The latest berry on the list and one of the best. Berries are extra large for its season and should be planted largely. Extreme late berries always sell at a high figure. Price, $60 \mathrm{c}$ per dozen; $\$ 3.00$ per 100.

THE MESSERAU.-A gentleman in New York purchased a quantity of Snyder blackberries. When they came into bearing one of these plants quickly attracted attention by its vigorous growth and berries which were much larger and sweeter than any other. The attention of Prof. Bailey, of Cornell University, was called to it who at ance pronounced it to be a new and distinct variety and named it Messereau in honor of the man who first recognized it. Its hardiness was demonstrated during the extreme winter of 1898-,99, when not a bud was injured and it bore twice as much as the snyder and of a much higher quality. It is certain the demand for plants will be very great for a long time to come. Price, $75 \mathrm{c}$ per dozen; $\$ 4.00$ per 100 . 


\section{Select Strawberries.}

No one owning a home, or for that matter having one rented for a term of years, can put a little money to better use than to buy three of four hundred plants of the standard varieties of strawberry. Give them the proper care and a good sized family will hardly use all the fruit they will produce the next season after planting. Nothing will bring quicker and greater satisfaction to the planter, more keen delight to his children, or lessen the burdens of his good wife in providing for the table than a well kept strawberry bed. The best time to plant strawberries is in early spring and on fertile, new soil, or old land brought to a high state of cultivation. . If horses are to be used in cultivating, plant in rows three and one-half to four feet apart, and one to three feet in the row, but for hand culture, one by two feet will answer. Here is the plan we have found the most profitable and always gives large, fine fruit: Set plants as early in spring as the season will permit; pinch off all the blossom stocks which appear
the first season; this throws

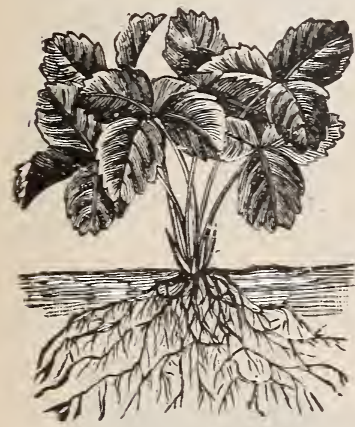

Right way. all the strength into a good stand of new plants for the next year. About November first cover with rye or wheat straw, just deep enough so they can come up through it; if too much is on remove a part of it when spring comes and leave the rest to keep the berries off the soil. Dig enough of these new plants to start a new bed, which treat as before, and as soon as the crop is off plow under the old bed, and keep this up year after year and you will have the finest fruit that can be produced. Our plants are strictly nursery grown and will give far greater satisfaction than can possibly be obtained with

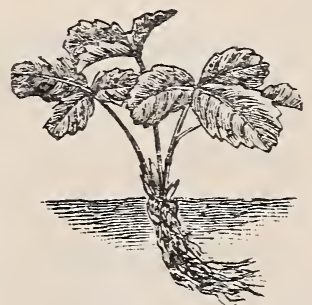

Wrong Way plants taken from an old fruiting bed. Such plants are not

worth the digging. Note those marked (P) are pistillates, having imperfect blossoms and should have a row of some staminate variety within fifteen feet or they will usually produce imperfect fruit.

We advise when making small beds for family use to plant in three rows

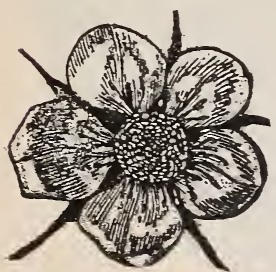
with a staminate variety in the center and pistillate varieties on either side, or when planting a field of them, every third row should be a staminate to insure perfect fertilization. Many ask, why not leave out the pistillate varieties, then we will have no trouble about fertilization? Our answer is that many of our very best and most profitable varieties are self-sterile and when intelligently managed they produce the finest fruit and by far the most of it. In selecting varieties for description we will restrict ourselves to those recognized as

Perfect Bloom. the best all around varieties for this and only recommend those we have tried and found worthy. We have

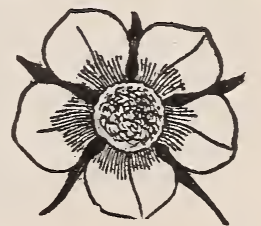

Imperfect B100m. many varieties of more or less value which we shall not describe for want of space.

Fifty at 100 , and 500 at 1,000 rates, only when the quantity taken is of one variety; an order for 500 plants calling for seven or eight varieties will not be filled at 1,000 rates.

BEDERWOOD.-(S)-This is much recommended as a fertilizer for all early pistillate sorts. Very early and productive. Berries above medium size and bright red color. Price, $25 \mathrm{c}$ per $25 ; 35 \mathrm{c}$ per $50 ; 70 \mathrm{c}$ per $100 ; \$ 3.00$ per 1,000 .

CRESCENT.-(P)-This is an old standard variety, which has made more money for the growers than any other ever introduced. Above medium size, bright red, good quality ànd a good shipper. Plant has clean, thrifty foliage and makes runners freely. Same price as Bederwood.

A Certificate of Nursery Inspection, certifying that our nurseries have been examined and found to be free from all insect pests, is attached to every order that leaves our nurseries. 
WARIIFID.-(P) - This has succeeded everywhere and with everybody. Sells well and ships well; bears immense crops of dark blood red berries. One of the very best for canning. Don't fail to plant some of this variety. Same price as Bederwood.

HAVERIAND.-(P)-This is a berry that is immensely productive everywhere. Medium in season, fruit large, light in color, needs near market, but for home garden nothing excels it in amount of fruit. Price, $30 \mathrm{c}$ per $25 ; 40 \mathrm{c}$ per 50 ; $80 \mathrm{c}$ per $100 ; \$ 3.50$ per 1,000 .

MARSHAII.-(S)-This berry we believe has no equal as an extremely large berry. Berry deep blood red to center, flavor very much like the wild berry. Foliage large and vigorous. While it will not perhaps yield as many quarts to the acre as some medium sized berries, yet it is the best extra large berry. It makes comparatively few runners and should be grown in hedge row to get the largest berries. Same price as Haverland.

BRANDYWINE.-(S)-Season medium to later. One of the finest berries we have yet tried; will surely become a great favorite. It is one of the heaviest fruiters. Berries very large, deep blood red to center. You should try this variety. Same price as Haverland.

GANDY'S PRIZE.-(S)-One of the most popular extra late sorts. The berries are large, cone-shaped and as even as a top, and perhaps as largely planted as any late vareity. It is very productive considering it ripens its berries nearly all at once and after most other varieties are running small, so the grower is still able to supply his customers with fine large berries. Same price as Haverland.

TrNNESSEE PROIIFIC.-(S)-Season early. This is one of the most productive berries we have ever grown; seems especially adapted to our light soil. A good shipper, dark red to center and of excellent flavor; will become very popular. One of the very best on our list. Same price as Haverland.

SAMPIE.-(P) - A berry of large size and fine quality; deep blood red to the center. Colors all over at once; will yield as well as the Haverland. A strong growing plant with perfect foliage. Same price as Haverland.

PARKER FARIE.-(S)-Probably the most productive late staminate berry grown. On light land is sets more fruit than it can mature; on rich, moist land under high culture it succeeds well. Fruit large, good quality, dark glossy red; makes few runners. Price, $35 \mathrm{c}$ per 25 ; $60 \mathrm{c}$ per $50 ; \$ 1.00$ per $100 ; \$ 4.50$ per 1,000 .

ROUGH RIDER.-(S)-Originated in Oswege county, New York, by Charles Learned. A seedling of Eureka, fertilized by Gandy. It is a good runner and enormously productive. Berries very large, color dark red like Gandy. What makes it especially valuable is its extreme firmness, which enables the grower to ship to very distant markets. It is also a late berry, which taken in connection with its great size and attractive appearance cannot fail to make it one of the most valuable varieties grown. Price, $35 \mathrm{c}$ per $25 ; 60 \mathrm{c}$ per 50 ; $\$ 1.00$ per $100 ; \$ 4.50$ per 1,000 .

STNATOR DUNIAP.-(S)-Season, early to late. A new berry just introduced last year. Our opinion from two years' trial is that it is equal to any variety on our grounds. Its fruit is a beautiful glossy red, fine shape and large. Growers will make no mistake by making a start with this variety. Price, $35 \mathrm{c}$ per $25 ; 60 \mathrm{c}$ per 50 ; $\$ 1.00$ per $100 ; \$ 5.00$ per 1,000 .

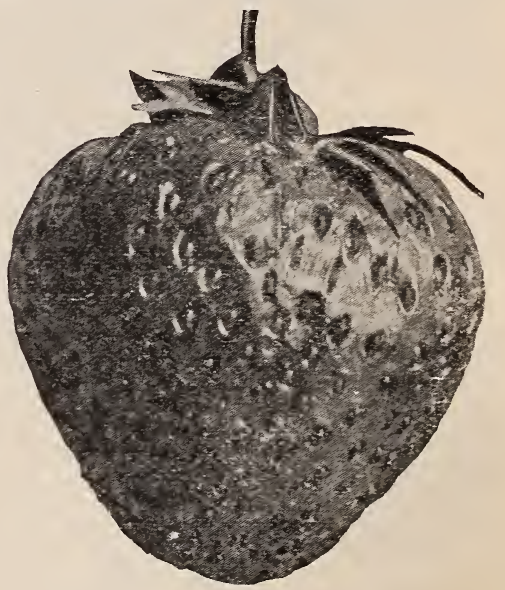

Senator Dunlap.

EXCEISIOR.-(S)-In all my experience in strawebrry culture I have never tested a berry which pleased me so much as this. It is rightly named, for it surely excels any other early berry yet introduced and will be a leader as the extra early berry both north and south. It was fruited in the same plat with all the other extra early sorts and first picking was four full days ahead of Michel. "The berries were larger han any ripening at the same season, very uniform in size and the last picking was very nearly as large as the first. Its color is a deep blood red and one of the very best shippers. It will take the highest rank at the south for a berry to ship north. You run no risk in planting this variety; adapted to both light and heavy soils. Same price as Haverland.

If you wish to get a few orders from your neighbors, write us for térms and addresS, IIN COUNTY NURSERY, CENTER POINT, IOWA. 
AROMA.-(S)-Season very late; size much above medium, bright red flesh to center and a good shipper. One of the best pollenizers for late sorts; well adapted to light soil and will not disappoint you. Same price as Haverland.

CLYDE.-(S)-Season, medium. It has been many years since a berry has been introduced which created such a furore among growers as this. Its strong points may be enumerated as follows: Enormously productive, berries large, cone-shaped, as pretty as a top, bright crimson to the center, and seems to succeed on all soils. By all means give this berry a trial. Same price as Haverland.

SPIENDID.-(S)-Above medium size, dark crimson, very productive and handles well; is said to have out-yielded Warfield. If we were going to select just one variety from our list to plant exclusively, it would be splendid. It is the most satisfactory berry we have ever planted. It is very uniform in shape and size, dark crimson color all over and the best in quality of any berry on our list. Makes plants freely, and they have abundance of bright, healthy foliage, never having shown a trace of disease. Same price as Haverland.

\section{Rhubarb or Pie Plant Roots.}

IINNAEUS.-Large, early, tender and fine. $10 \mathrm{c}$ each; $\$ 1.00$ per dozen; $\$ 5.0$; per 100

VICTORIA.-A large variety of excellent quality. Same price as Linnaeus

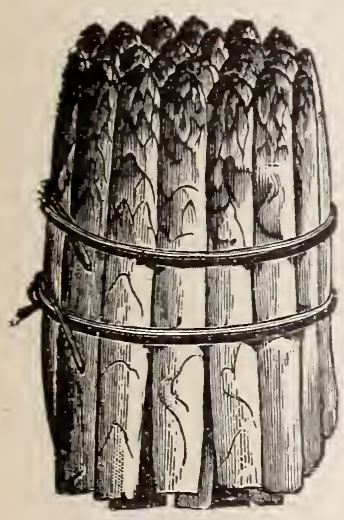

\section{Asparajgus.}

Asparagus is one of the earliest and finest of spring vegetables; so easy of culture, profitable and health-giving that every family garden should have a very liberal supply. Plant in well-drained fertile soil, work it up fine and deep, and place the plants in rows four feet apart, and eight inches apart in the row; spread out the roots in a trench made deep enough to permit their crowns to be covered with three or four inches of mellow soil; give the rows a liberal dressing of well-rotted manure at least once a year, and 15 1bs. of salt per rod length early every spring. Do no cutting for use the first season. Any or all of the following described varieties will give entire satisfaction if managed as abore.

COIUMBIAN IMAMMOTF WHITE.-A distinct variety of strong, vigorous growth, producing very large white shoots that in favorable weather remain white until three or four inches high, or as long as fit for use. Market gardeners and those growing for canners will find this a very profitable variety. Price, 2 year roots, $50 \mathrm{c}$ per dozen; $75 \mathrm{c}$ per $25 ; \$ 1.25$ per $50 ; \$ 2.00$ per $100 ;$. Price, 1 year roots, $40 \mathrm{c}$ per dozen; $60 \mathrm{c}$ per $25 ; \$ 1.00$ per $50 ; \$ 1.50$ per 100

PALMITTO.-A very early variety extensively grown for early markets; even regular size of excellent quality, and considered by many as the best variety in cultivation. Prices same as above.

CONOVER'S CorOSSAI.-A mammoth variety of vigorous growth; tender and excellent quality; sends up 15 to 20 sprouts each year, one inch $\mathrm{n}$ diameter; color deep green, and crown very close. Prices same as above.

No family should be without plenty of fruit for the home table and for canning-better have a little surplus than to go a little scant. Send us your order and you will soon have an abundance and to spare. 


\section{Select Evergreens.}

The following are the best sorts of evergreens to plant in this part of the state for shelter belts and ornament. There is nothing which will add more to the value of a form or more comfort to the hame than a well arranged plantation of evergreens. Their shade is cool and refreshing in summer, and a belt of them is the greatest barrier against winter blasts which can be provided Our evergreens have been two and three times transplanted, are heavy rooted and stocky, thrifty plants.

HOW TO PIANT AND CARE FOR EVERGREINS.

First-Any soil that will grow corn and garden vegetables is suitable for evergreens.

Second-Dig holes large, so that roots are not crowded, using top soil in bottom of hole and also arranging the roots carefully, working the fine soil around and among the roots with your hand. Shake the tree occasionally as the filling is going on, to settle the soil, at the same time raising the tree to the desired depth. When the roots are well covered hold the tree upright and firm while you tread the soil very firmly around the tree with the feet; when this is done you have a basin or hole around the tree that will hold one-half to a pail full of water, according to size of tree. Fill this basin with water, after it is all soaked away-say in half an hour-fill the basin with good mellow soil, which must be left loose and not tramped.

Third-Take your tree to place of planting, well covered with wet moss and blankets, dipping each root in barrel or bucket of water just before placing in hole.

Fourth.-The month of August is the most critical time for newly planted evergreens, for during this month, unlike deciduous trees, evergreens make a new root growth, therefore require moisture. If rains have not been plenty the trees should be watered. Make a basin around each tree by pulling away the soil with a hoe and water exactly as described above in article No. two. If the season is dry, this watering should commence the latter part of July, repeating every two weeks until it rains.

Fifth.-Good cultivation is very essential. No vegetation appreciates good cultivation better than trees, which can be done by hoe or horse cultivator, twice a week up to August 1st, when a good mulch of partly rotted hay or straw should be given. Never mulch with green manure.

Sixth.-Seedling evergreens, the largest sizes should be planted and treated as above; small sizes should be planted in well prepared beds with dibble and shaded the first season.

Seventh.-Distance apart for wind breaks: Spruces, Firs and Arborvitaes, single row, 4 to 6 feet; double row, 10 feet. Scotch and Austrian Pines, single row, 8 feet; double row, -0 to 12 feet. White Pine, single row, 10 feet; double row, 12 to 14 feet.

Eighth.-Evergreen hedge. American Arborvitae, sizes from 10 to 18 inches, 15 inches apart; 18 to 24 inches, 18 inches apart; 2 to 3 feet and larger, 2 feet apart; Spruce, 2 to 4 feet apart, according to size.

WHITE PINF.-One of the best evergreens. Foliage is a warm light green often with a bluish tinge. The leaves in fives, three or four inches long, soft and delicately fragrant. It does not grow so rapid the first few years as some, but after being planted eight or ten years, it is the most rapid grower of all evergreens. It accommodates itself to a great variety of soils; it is one of the best for shelter, the best large growing evergreen to plant near buildings or along streets to be trimmed up for shade. But few, if any other trees, unite so many elements of beauty and utility as our native White Pine.

PINUS PONDFROSA.-(Of Colorado.)-Heavy wooded pine, a rapid grower, forming a tree of great size. Bark reddish and foliage longer and coarser than the Red or Norway Pine. A valuable tree for the west and northwest. Well adapted to dry, windy and exposed positions. It is a native of western $\mathrm{Ne}$ braska and will do well on our light, dry, sandy soil.

SCOTCH PINO.-(Pinus Sylvestris.)-A rapid growing, hardy variety, with stout, erect shoots, and silvery green foliage. Valuable for shelter and makes a good lawn tree, and being one of the hardiest of the evergreen family, it readily adapts itself to the trying climate of Minnesota, the Dakotas and Montana. It also thrives well on the dry plains of Kansas, and is perfectly at home in Illinois, Nebraska, Iowa and other states.

BAISAM FIR.-(Picea Balsamea.)- A well-known, popular tree, very handsome while young, assuming the upright, conical form; leaves dark green above, silvery beneath; retains its color throughout the severest winter weather; grows quite rapidly when established; desirable every way. 
CONCOIOR FIR.-(Picea Concolor of Colorado.)-This evergreen is of the rarest beauty,-even colored, the same the year round, a rapid grower and will make a large tree; in this section of country should be planted where it will have some protection from southwest winds and sun; this should be included in every collection.

AMERICAN WHITE SPRUCE.-Pyramidal tree of dense growth, with light, silvery green foliage. A more compact tree in all respects than the Norway Spruce. One of the best for general use and very fine for lawn planting.

BIACK HIIIS SPRUCE.-This is the Picea Alba or the White Spruce, but with this difference: That while the Norway and the Black and White Spruce will not endure the winter drouths of the western plains, this tree seems well adapted for all the regions from which the others are excluded. Growing in a dry climate and often richly colored, it seems to meet the requirements of a vast field. While the air of the plains has but about 50 degrees of moisture to 90 degrees in the eastern states, it is necessary to have something which will endure the bright sun and drying winds of winter.

NORWAY SPRUCE.-(Abies Ixcelsa.) - A very popular variety from Europe, It has been more extensively planted in this country than has any other evergreen. In fact, it is so well known as being one of the best evergreens for ornamental purposes that it is only necessary to say that it is also the most valuable for wind breaks, screens and hedges.

PICAF PUNGENS or SIIVER SPRUCE.-(Also called Colorado Blue.)-This is the King of Spruces, clothed in royal robes of silver and sapphire, a very Kohinoor among the gems of the Rockies. It is a child of the storm king, growing at an altitude of from 8,000 to 10,000 feet above the level of the sea. It is generally found ever there in deep gorges or on the north of the ranges. We would naturally suppose that is could not endure a sudden change or thrive in a hot climate. There are some fine specimens growing in Washington, also in North Carolina. The question arises, while the tree endures such a diversity of climate, why- is it never found on the lower altitudes or among the foot hills? The answer is, it could not possibly grow there. The Douglass, the Ponderosa and Concolor have larger seeds and send out a strong plant, and therefore they are found lower down. Pungens seed is small about 110,000 to the pound. In the higher altitudes are frequent showers and often moss in the woods, and the ground is seldom dry. It is not hot enough to kill the plants, and so, on the altitudes, nature has provided for their propagation. The cone on the Pungens is about one-half the size of that of the Norway. The needles are short and sharp-pungent-hence the name. They are polished like glass.

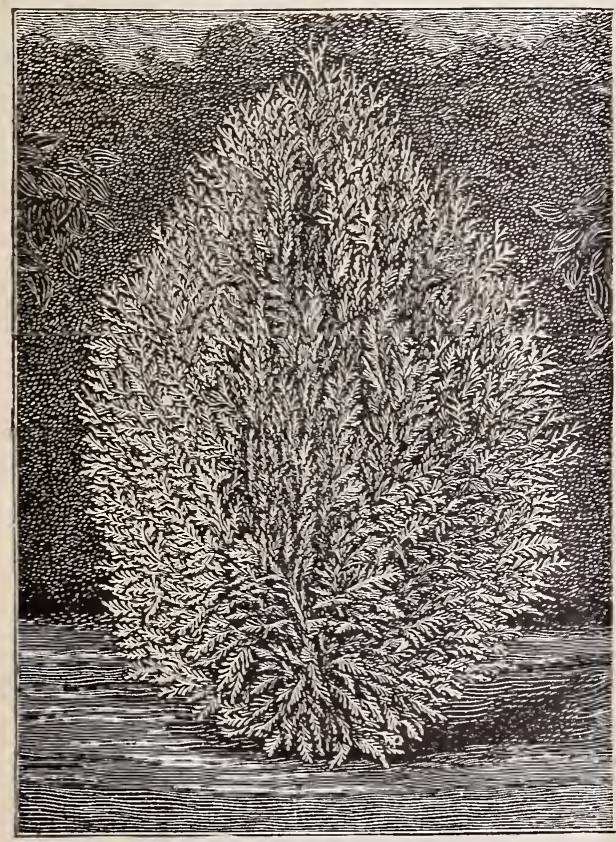

American Arbor Vitae (Thuyo Occidentalis.)

JUNIPER VIRGINIA, RED CEDAR - A well-known American tree which varies much in habit and color of foliage. It succeeds well on the plains of Nebraska and Kansas where other evergreens fail and is very desirable for ornamental purposes; also for windbrakes, shelter belts and hedges.

AMERICAN ARBORVITAE.(Thuyo Occidentalis.)-One of the finest evergreens for ornamental screens and hedges. It grows rapidly and soon forms a most beautiful hedge. It bears trimming to any extent desired and plants that have been rendered compact by clipping, retain the fresh green of their leaves in winter better than those with more open foliage. For an ornamental hedge the plants may be set twelve to sixteen inches apart. For a screen to grow tall, plant about two feet apart.

PYRAMIDAI ARBORVITAE. A supurb, new and hardy sort of very compact habit; much better than the Irish Juniper; grows in a perfect column; is rare and beautiful, and is largely planted in cemeteries, owing to the small amount of space it occupies. This

is perhaps the most valuable Arborvitae in cultivation.

ROCKY MOUNTAIN SIIVER CFDAR.-A tree of rare beauty, almost equal to Silver Spruce. Naturally assumes an upright form. Deserves a prominent position on the lawn. Coming originally from the Rocky Mountains, it is entirely hardy and well adapted to our climate. 


\section{Price List of Evergreens.}

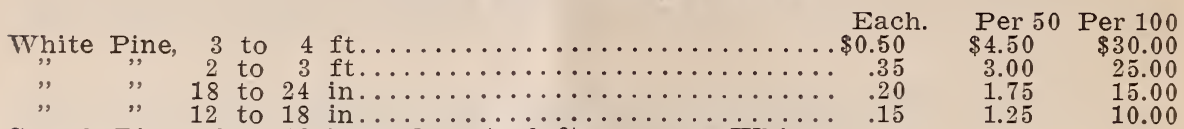

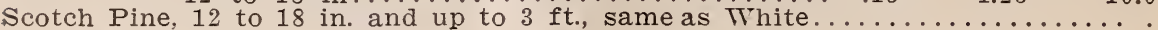
Pine.

Norway Spruce
White Pine.

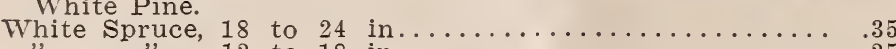

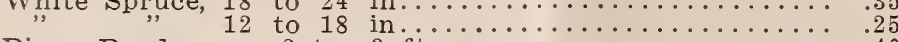

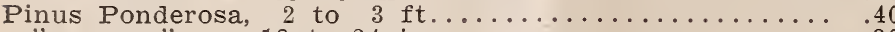

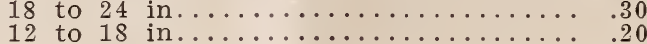

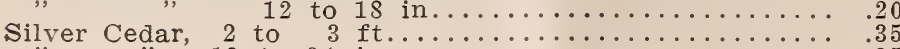

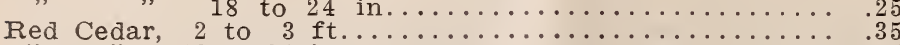

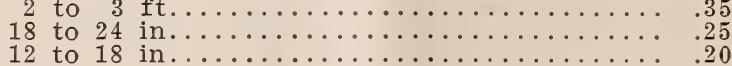

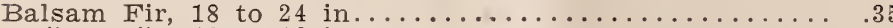

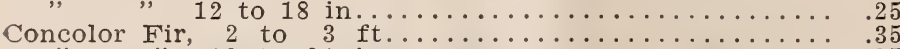

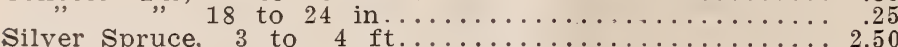

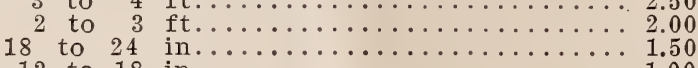

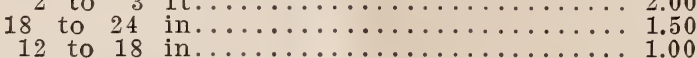

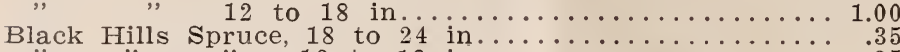

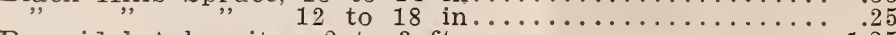

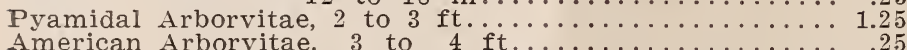

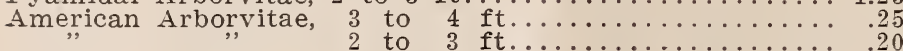

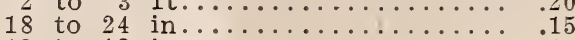

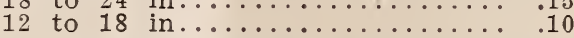

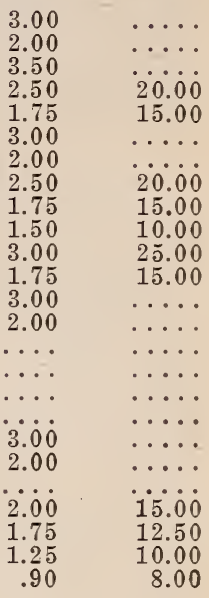

\section{Shade and Ornamental Trees.}

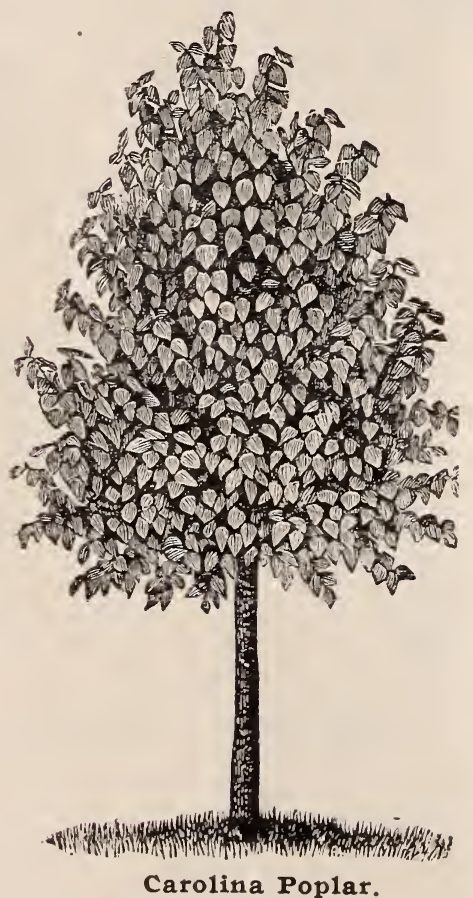

Carolina Poplar.

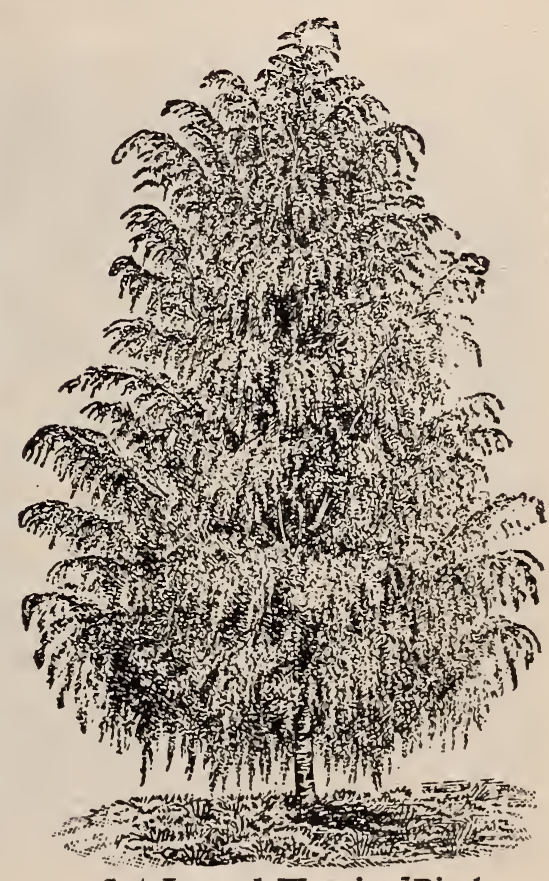

Cut-Leaved Weeping-Birch.

CAROIINA POPLAR.-Pyramidal form and robust growth; leaves large, glossy, serrated, of light green color, changing to dark green. Makes a very handsome shade or street tree. Smoke and soot of large cities do not damage its foliage. Perfectly hardy. Price, 12 to $14 \mathrm{feet}, 40 \mathrm{c}$ each; 10 to 12 feet, $35 \mathrm{c}$ each; 8 to 10 feet, $30 \mathrm{c}$ each; 6 to 8 feet, $25 \mathrm{c}$ each; 4 to 6 feet, $20 \mathrm{c}$ each; 1 year. 2 to 3 feet, $\$ 5.00$ per $100 ; 1$ year, 1 to 2 feet, $\$ 4.00$ per 100 . 
SUGAR MAPIE or HARD MAPLE.-One of the most beautiful shade or ornamental trees; when given plenty of room form a fine, round, dense head. In autumn its foliage presenting varying and beautiful colors as cold weather approaches; and often becomes gorgeously colored. Price, 8 to 10 feet, $50 \mathrm{c}$ each; 7 to 8 feet, $45 \mathrm{c}$; 6 to 7 feet, $40 \mathrm{c}$; 5 to 6 feet, $35 \mathrm{c} ; 4$ to 5 feet, $30 \mathrm{c}$; 3 to 4 feet, $20 \mathrm{c}$.

EUROPEAN WHITE BIRCH.-A rapid growing shade tree of beautiful form. Tery desirable for street or lawn planting. By the time the tree is five or six years old the bark of the trunk and larger branches becomes a beautiful silvery white color. Entirely hardy in all parts of the northwest. Makes elegant shade. Price, 6 to 7 feet, $40 \mathrm{c}$; 5 to 6 feet, $35 \mathrm{c} ; 4$ to 5 feet, $30 \mathrm{c} ; 3$ to 4 feet, $25 \mathrm{c} ; 2$ to 3 feet, $20 \mathrm{c}$.

IINDEN.-(Commonly called Basswood.)-A very graceful and beautiful tree for planting on the lawn. Its leaves are moved with the least breath of air and show the white surface underneath. Its blossoms are delightfully fragrant and the busy bee delights in their sweetness. Price, 7 to 8 feet, $50 \mathrm{c} ; 6$ to 7 feet, $40 \mathrm{c} ; 5$ to 6 feet, $30 \mathrm{c} ; 4$ to 5 feet, $25 \mathrm{c} ; 3$ to 4 feet, $20 \mathrm{c} ; 2$ to 3 feet, $15 \mathrm{c} ; 1$ to 2 feet, $10 \mathrm{c}$.

CATAIPA SPECIOSA.-A very hardy tree with large, tropical appearing foliage and a free bloomer, followed by long bean-like pods. Desirable for shade and street trees. Price, 8 to 10 feet, $50 \mathrm{c} ; 7$ to 8 feet, $40 \mathrm{c}$ each.

MOUNTAIN ASH.-(Oak leaved.)-A handsome and hardy variety, with large and deeply lobed leaves, distinct and fine, covered in autumn with bright scarlet berries. Price, 5 to 6 feet, $50 \mathrm{c}$ each.

\section{Weeping Trees.}

WIER'S CUT-IEAVED MAPIE.-A variety of the silver-leaved and one of the most remarkable and beautiful trees, with dissected foliage. Ranks among the most attractive lawn trees. 6 to 8 feet, $40 \mathrm{c}$.

BIRCH.-Cut-leaved, weeping. Unquestionably one of the most popular of all weeping or pendulous trees. Its tall, slender, yet vigorous growth, graceful drooping branches, white bark and delicately cut foliage present a combination of attractive characteristics rarely met with in a single tree. Perfectly hardy, as is shown by the fact that perfect, full grown specimens are seen in Minnesota, where the mercury drops to 30 and 40 degrees below zero. Price, 6 to 8 feet, $\$ 1.50$ each.

TEA'S WEFPING MUIBERRY.-Another season's growth fully sustains what we have heretofore claimed for this remarkable tree-unequalled in gracefulness and beauty, combined with the strongest vigor, health and hardiness. And the unsolicited testimony of many having them growing in various parts of the country, from Wisconsin and Canada to Florida-from the bleak hills of New England, the sunny vales of California and the arid plains of Texas-all confirm our claim that it is the best hardy weeping tree ever produced. Price, 2 year heads, $\$ 1.50$ each.

CAMPERDOWN WEFPING EIM.-This forms one of the most picturesque drooping trees. It is of rank growth, the shoots often making a zigzag growth outward and downward of several feet in a single season; the leaves are large, dark green and glossy and cover the tree with a luxuriant mass of verdure. Price, 2 year heads, $\$ 1.50$ each. 1 year heads, $\$ 1.25$.

\section{Ornamenta1 Trees.}

BECHTEL'S DOUBIE FTOWERING AMERICAN CRAB.-A medium sized hardy ornamental tree of great beauty. When in bloom this tree presents the appearance of being covered with roses, scenting the atmosphere for a long distance with the perfume equal to that of any rose. Unlike many other trees, it does not bloom until the leaves are fully developed, which adds greatly to its beauty. Price, 4 feet, $50 \mathrm{c}$ each.

RUSSIAN OIIVE.-An extremely hardy tree, with silver foliage, and the most delightfully fragrant when in bloom of anything we have a knowledge of. A small sprig taken into the house will perfume it throughout; the tree attains only medium size. Price, 4 to 5 feet, $30 \mathrm{c} ; 3$ to 4 feet, $25 \mathrm{c} ; 2$ to 3 feet, $20 \mathrm{c} ; 1$ to 2 feet, $15 \mathrm{c}$.

HORSE CHESTNUT.-A very popular tree for street or lawn planting. Hardy and covered in early summer with magnificent spikes of flowers. Price, 5 to 6 feet, $50 \mathrm{c}$ each.

\section{Ornamental Shrubs and Flowering Plants.}

SIBFRIAN PEA TREE.-In introducing this tree, we do so feeling assured of the advantages gained, particularly in our prairie sections, will be speedily realized as a matter of economy and extreme usefulness. The great merit of this beautiful shrub not only lies in its attractive appearance as a lawn shrub, but serves as a wind break or hedge, having a dense mass of pea shaped flowers of 
a delicate yellow, tinted to a deep orange, which might truly be called the tree of gold, blooming in early spring and throwing forth its sweet scented odor, which can be detected a long distance. The extreme hardiness of this wonderful tree makes it all the more valuable. being a native of northern Russia. Price, 2 to 3 feet, $35 \mathrm{c}$.

SNOWBAIL.-A well-known shrub; produces its snowy white flowers in large balls or masses in June; for the best effect trim into a round ball-shaped bush. Price, 2 to 3 feet, $30 \mathrm{c}$ each.

SYRINGIA or MOCK ORANGE.-One of the most desirable shrubs. Its beauty and fragrance make it a universal favorite. They grow to a height of eight or ten feet and bloom profusely in the spring. Price, 2 feet, $25 \mathrm{c}$ each.

SPIRAF VAN HOUTTE.-Graceful, with long drooping sprays, studded thickly with handsome, pure white flowers, hence the name, "Bridal Wreath." The grandest of all. Price, 18 to 24 inches, $25 \mathrm{c}$ each.

HYDRANGEA PANICUIATA GRANDIFIORA.-A fine shrub and very popular, quite hardy, easy to grow and blooms the same year they are set out. The flowers are in immense panicles, creamy white when first open, changing to pure white when fully out and turning pink and bronze with age, blooms during August and September. The flowers will be larger and finer if given good rich soil, and the plants cut back each spring fully one-half the past season's growth. Price, 18 to 24 inches, $25 \mathrm{c}$ each; 2 to 3 feet, $35 \mathrm{c}$ each.

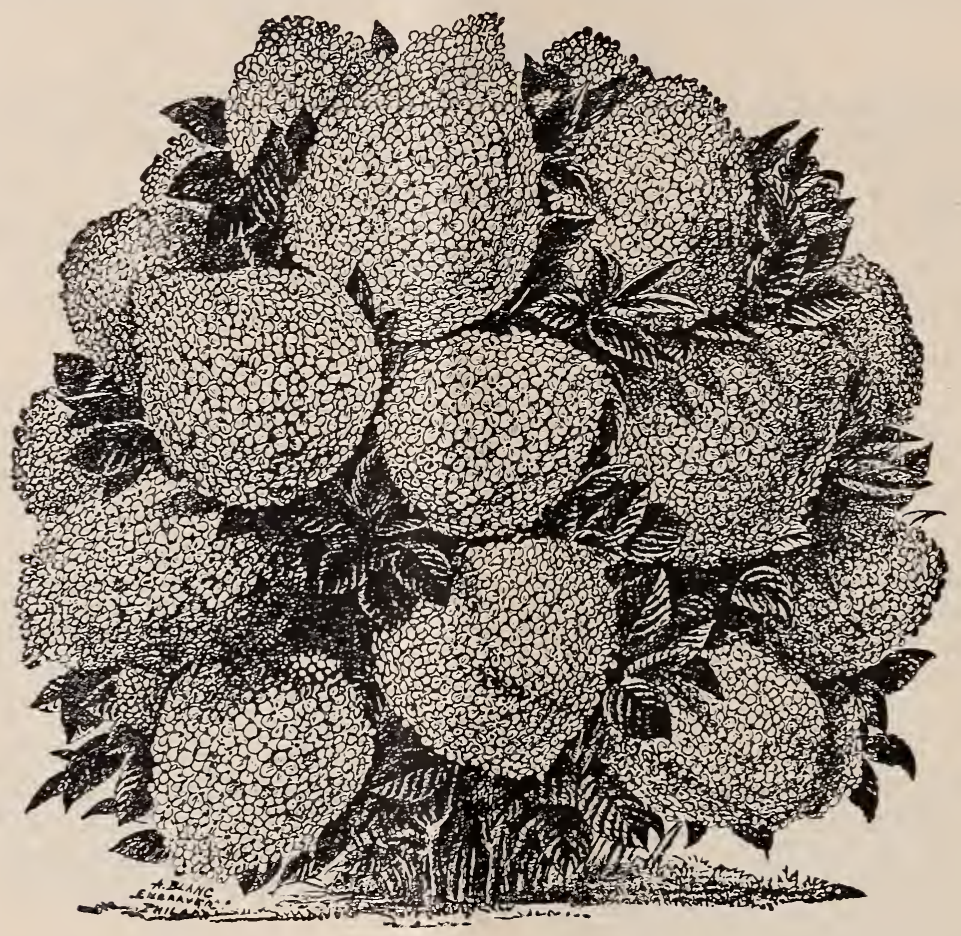

Hydrangea.

GOIDEN GIOW.-A hardy perennial plant, growing eight feet high; branching freely and bearing by the hundreds on long, graceful stems, exquisite double blossoms of the brightest golden color and as large as the Cactus Dahlia. Price, strong roots, $25 \mathrm{c}$ each.

YUCA FIIAMENTOSA.-An interesting and tropical appearing plant, which will endure any of our northern winters and is therefore valuable for those localities where flowering plants are scarce. It is an evergreen perennial, throwing up in the middle of the summer flower stalks three feet in height, bearing a profusion of creamy white, bell shaped blossoms. One of the most beautiful plants for the lawn. Price, 2 year plants, $50 \mathrm{c}$ each.

Eat fruit and enjoy life all you can, for you'll be a long time dead.-Casey. 
EUIAIIA ZEBRINA JAPONICA.-These plants form one of the most beautiful objects that can be grown. They are striped and spotted grasses, forming a dense clump and growing 5 to 10 feet high. They bear large, feathery plumes, which are exceedingly odd and handsome, especially when dried and used for winter decoration. As a lawn plant they have no superior. Price, 50c each.

TRUMPET FLOWFR.-A splendid vine, vigorous and hardy, and a very rapid grower, well adapted for covering unsightly objects. The flowers are magnificent, being fully four to five inches long and in clusters. Price, 25c each.

\section{Clematis Vines.}

JACKMANNII. - This is perhaps the best known of the newer fine perpetual Clematis, and should have credit of the great popularity now attending this family of beautiful climbers. The plant is free in its form of growth and an abundant and successional bloomer, producing flowers until frozen up. The flowers are large, of an intense violet purple, remarkable for its velvety richness. The Jackmannii has no superior. July to October, Price, strong field-grown, $75 \mathrm{c}$ each

MADAME FDOUARD ANDRE.-(The Red Clematis.)-An entirely distinct and most novel variety, and the nearest approach to a bright red ever sent out. The plant is a strong, vigorous grower, being a hybrid of the popular Jackmannii, which it resembles in freedom of bloom, strong, vigorous growth and shape and size of flower, but is a distinct carmine red color of a most pleasing shade, entirely different from all other varieties. Price, strong field-grown, $75 \mathrm{c}$ each.

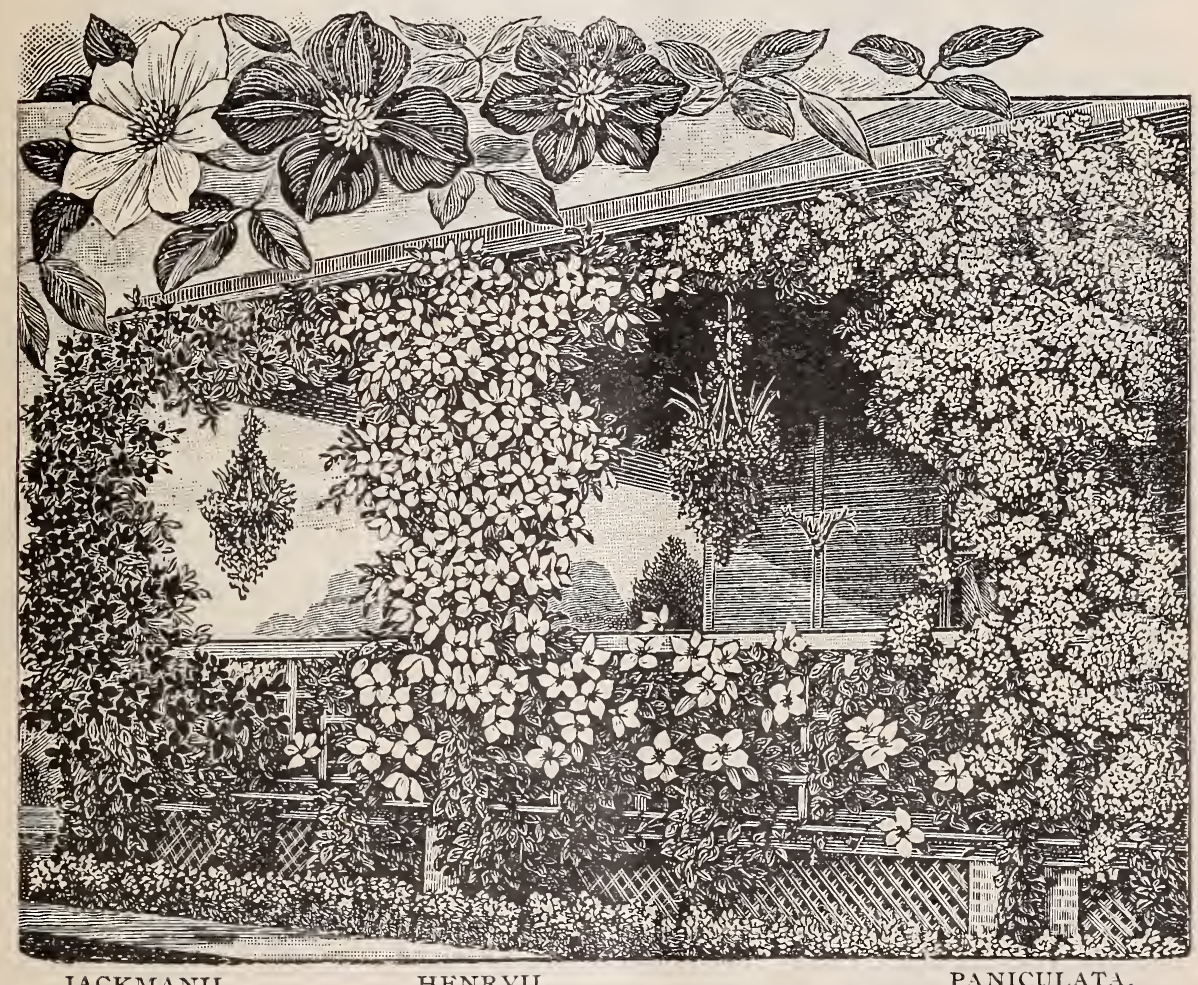

JACKMANII.

HENRYII.

PANICULAT.A.

CIFMATIS PANICUIATA.-This wonderful flower blooms in July and lasts until September. It is one of the finest of hardy climbers, with handsome foliage, of very vigorous and rapid growth, and produces in late summer dense sheets of medium sized pure white flowers of the most pleasing fragrance. Each branchlet is thickly set with these showy flowers, and altogether produce a most gorgeous sight. This is a new Japanese plant and perfectly hardy and finely adapted to use for any covering purpose. Price, strong field-grown, 50c each.

HENRYI. - The best and most popular of all the white varieties. Fine, large, creamy white flowers. A strong grower and very hardy; a perpetual bloomer. Price, strong field-grown, $75 \mathrm{c}$ each.

WISTARIA.-(Chinese.)-A most beautiful climber of rapid growth, when well established growing at the rate of 15 or 20 feet in a season, and producing long, pendulous clusters of pale blue flowers, resembling in size and shape a bunch of grapes; sometimes gives a second crop of flowers in the fall. Price, 2 year plants, $50 \mathrm{c}$ each. 


\section{Roses.}

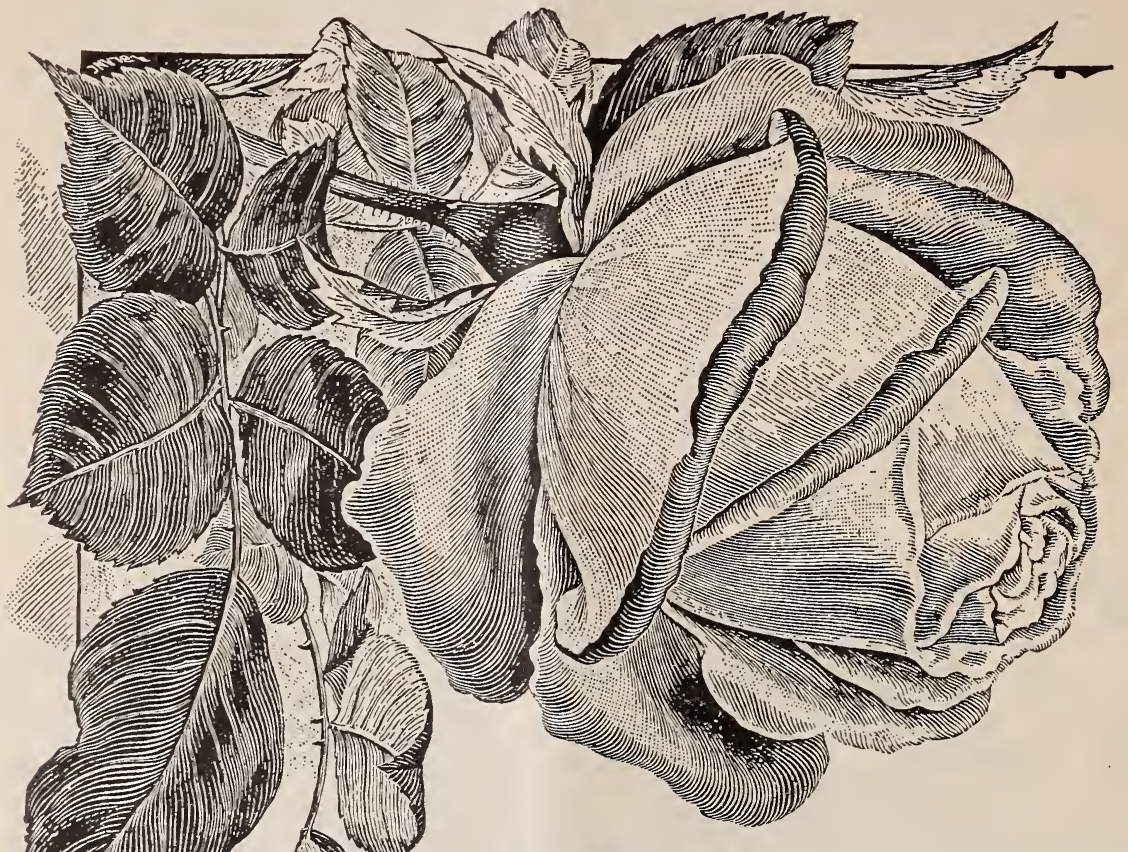

BAITIMORE BEIIE.-Pale blush, shading to rose color, very double, flowers in beautiful clusters, the whole plant appearing a perfect mass of bloom. One of the best climbing roses, but must be protected in winter. Price, 2 year I blooming plants, 50c each.

CRIMSON RAMBIER.-This rose is unquestionably an acquisition, a novelty of high order, and most distinct in its characteristics. It is a running or climbing rose of vigorous habit strong and rapid grower, with handsome, shining toliage, and produces in marvelous abundance clusters of the brightest crimson semi-double roses. Its clustered form, its brilliancy, the abundance of its bloom, and the great length of time the flowers remain on the plant without falling or losing their brilliancy, are qualities which will make this new claimant for admiration an assured favorite. For verandas, walls, pillars and fences, it is a most suitable plant. Price, 2 year blooming plants, $50 \mathrm{c}$ each.

WHITE RAMBIER.-Thalia.)-Pure white, of very strong and vigorous habit of growth. Free bloomer and handsome. 2 year blooming plants, $50 \mathrm{c}$ each.

GREVIILE, or SEVEN SISTFRS.-Blooms in large clusters, with flowers varying from white to crimson. Luxuriant dark green foliage; perfectly hardy. Price, 2 year blooming plants, 50c each.

PRAIRIE QUEFN.-The well-known climber. Flower double, beautiful pink. fading to nearly white. Price, 2 year blooming plants, $50 \mathrm{c}$ each.

GIORY OF IMOsSEs.-Pale rose, very heavily mossed; one of the best. Price, 2 year blooming plants, $50 \mathrm{c}$ each.

IUXFMBOURG MOss.-Large cupped and a very fine rose. A luxuriant grower and free bloomer. Price, 2 year blooming plants, $50 \mathrm{c}$ each.

MADAME PIANTIFR.-Pure white; produced in great abundance early in the season. One of the best of the hardy white roses. Price, 2 year blooming plants, $50 \mathrm{c}$ each.

GENERAI JACQUEMINOT.-This might be called the rose for the million, for it is still a universal favorite. Bright crimson-scarlet, exceeding rich and velvety. Grown more extensively than any other rose, especially for winter. Price, 2 year old blooming plants, $50 \mathrm{c}$ each.

PAUI NEYRON.-Flowers of immense size, often 5 inches in diameter; color deep, clear rose, very fresh and pretty. The plant is a strong, healthy grower, with clean, glossy foliage, and one of the most constant and prolific bloomers in the Hybrid class; yaung plants in nursery rows bloom almost without intermission, from June to late October. Price, 2 year blooming plants, 50c each. 
PRINCE CAMILIE DE ROHAN,-Deep velvety crimson, very dark, almost black, darkest of all; very large, moderately full; a splendid rose, the best of its kind. By all means include this in your collection. Price, strong blooming size, 2 year, $50 \mathrm{c}$ each.

\section{Double Herbaceous Paeonies.}

The Herbaceous Paeonies have always held an important place among hardy plants, and with the wonderful improvements made during recent years have established themselves among the leaders for popular favor

Their requirements are so simple, a good, rich, deep soil and an open, sunny position, if possible, which, however, is not absolutely necessary, as they thrive almost equally as well in a partially shaded position, and a liberal supply of water through their growing season, being sufficient to give an abundance and wealth of flowers which rival the finest roses in coloring and fragrance, and produce during their flowering season a gorgeous effect not equalled by any other flower.

We have during the past season feasted our eyes on the glowing splendors, and enhaled the delicate fragrance of many varieties in full bloom.

Why these beautiful and fragrant flowers have been neglected so long, is owing to the fact that people are not acquainted with them. You need only to see them and you acknowledge their excellence. They are the flowers that never fail; no disease affects them; they are hardy in the frozen north and in the sunny south, requiring no protection whatever, and once planted take care of themselves, increasing in size and beauty each year. Truly a plant for everykody.

Plant in the fall, if possible, or very early in the spring. It is cruel to send for them when leaved out. Plant in September and in November they will have rootlets as long as your finger. Have the ground rich and spade it two feet deep. Plant your roots with the crowns about three inches below the surface, and keep out the weeds and you can let them stand five years. We take pleasure in being able to offer our friends the following very choice list at reasonable prices; they are strong divided roots and few of them will fail to bloom the first season after setting.

I. ESPERENCE.-Is among the finest France has given us. It is in the Diamond list which marks the very best in the collection of a leading French florist. It stands in the front rank also of M. Koster, of Holland. They are fine prolific bloomers, vibid rose color, compact in form, early bloomers, making them valuable for cut flowers and decorations. They are highly perfumed, very vigorous and multiply rapidly. These can now be had at so heasonable a rate that they should be in every collection. Price, 50c each.

ANDRE IARUES.-Is deep, bright red, very double, a grand flower, and it loves deep, rich soil. Price, 25c each.

MARIE IEMOINE.-This flower fills all the requirements we demand of our favorites. It is as sweet as a rose. It opens slightly yellow then fades to purest white. It is a wholesale bloomer, a very winsome and attractive flower. Never leave this out of your collection. Price, $50 \mathrm{c}$ each.

FRANCOISE ORETGAI.-Is of French origin. It is very brilliont crimson, giving us a blaze of splendor, so deep as to verge on the purple. It is a vigorous and striking flower with a delightful, spicy fragrance. No collection can be full without it. Price, $50 \mathrm{c}$ each.

GRANDIFIORA AIBA.--Is a queenly flower, at first slightly tinted, with cream center and red dots in the middle. Then it fades to purest white, when its fragrance and beauty charm the beholder. Price, $30 \mathrm{c}$ each.

RUBRA TRIUMPHANT.-Has flowers of brilliant glowing crimson. They are also sweet scented. They do not bloom as soon as some others. The plants seem to require age. Just wait; give them a chance and they will more than make up for lost time. Price, $25 \mathrm{c}$ each.

GRANDIFIORA RUBRA.-Is a very king among flowers. It is one of the latest. It seems to hold itself in reserve gathering strength to put forth an exhibition of splendor. The flowers are of immense size, intense and glowing with effulgence. Massive and grand it brings up the rear of this great army of paeonies 2,000 strong. You look at them and think the best has been reserved till the last, and yet it is hard to call any one the best in this great procession which has during the season passed before us. Price, $30 \mathrm{c}$ each.

RICHARDSON'S RUBRA-Deep crimson with purple shading, a grand fragrant, ful orbed flower. Price, $75 \mathrm{c}$ each.

IA TUIIPE.-A fragrant, solid fine flower, exceedingly beautiful in the bud, when it shows an interlacing of crimson bands; when it opens it is flesh colored streaked with red; a great bloomer. Price, 50c each.

FESTIVA MAXIMA.-It is a large ball of white, with center petals dashed with red; my special favorite for a white flower. Price, $50 \mathrm{c}$ each.

AGNES MARY KEIWAY.--Sweetly fragrant, light rose guard, yellow petaloids, with rose tuft; a most lovely flower. $50 \mathrm{c}$ each.

TENUIFOIIA, or THE FERN IEAVED PAEONY.-Is a very rare, unique flower; it is one of the first to bloom. Price, $50 \mathrm{c}$ each. 
THF BRIDF.-A small, delicate, sweet flower; winsome, attractive and well named. Price, $40 \mathrm{c}$ each.

GRANDIFIORA CARNEA PIENA.-Full orbed, robust and grand; packed solid with its lovely pink petals; a charming flower of medium season. Price. $40 \mathrm{c}$ each.

RICHARDSON'S PFRFECTION.-Large, late, light flesh, melting to white. Price, $30 \mathrm{c}$ each.

GOIDEN HARVEST.-Worthy a place in the front rank; it is sweet in fragrance, a full bloomer, and better than many costly foreigners. Price, $30 \mathrm{c}$ each.

RFrvesI.-Immense flower, free bloomer; light rosy pink, center petals splashed with red. Price, $30 \mathrm{c}$ each.

MADAIME CHAUMY.-Is a late pink; perfect in form and very fragrant; would do best in partial shade, as its buds are a little sensitibe of the direct rays of the sun. Price, $30 \mathrm{c}$ each.

ALBA SUIPHURIA.-This is a fine flower and a favorite. Price $25 \mathrm{c}$ each.

POTTSII-A splendid flower, deep crimson. Price $30 \mathrm{c}$ each.

FDUIIS SUPERBA.-Light pink, very fragrant. Price, 25c each.

IRAGRANS.-An excellent variety. Price, $15 \mathrm{c}$ each.

\section{THE TUIIP.}

The Tulip is so perfectly hardy and so easily cultivated that it never fails to please. No country is too far north to grow them in perfection, where inhabited by civilized people. We know of nothing that for the amount of money invested will give a more gorgeous show during early spring. They thrive well in almost any soil and are sure bloomers, and for several weeks in early spring, before other flowers have come to remind us that "spring is here," they are dazzling in their beauty and a source of constant delight. They should be planted during October and November. Plant three inches deep in rows nine inches apart. Allow the ground to freeze before putting on their winter covering which should consist only of well rotted manure. If it is desired to continue them it will be best to take them up in the summer as soon as the stalk has died down and put them away in a cool, dry place till about the middle of October, when they may be planted as above directed. In taking them up the small bulbs may be planted as above directed. In taking them up the small bulbs may be separated from the old ones, and they planted at the same time in a close bed where they should grow one year and then be taken up and treated as above for flowering bulbs. Tulips also succeed admirably in pots or boxes for sitting room or parlor decorations during winter. In ordering these do not make the mistake to stop with a half dozen or dozen. Fifty will make a nice little bed, but 100 will please you more than twice as well. The following varieties will be sent postpaid as per list following.

DOUBLF YEITOW, DOUBIF WHITE, DOUBIF ROSE, DOUBIE RED, DOU. BIE VARIAGATED. $-5 \mathrm{c}$ each; $45 \mathrm{c}$ per dozen; $\$ 3.00$ per 100 , assorted to suit purchaser. 100 .

SINGIE.-In separate colors as above. 4c each; $35 \mathrm{c}$ per dozen; $\$ 2.50$ per

\section{Miscellaneous.}

RAFrIA.-Best Madagascar, for tying buds. Price, per 1b., 15c; 10 1bs., $12 \frac{1}{2} \mathrm{C}$ per Ib.

GRAFTING THREAD.-Unwaxed at $10 \mathrm{c}$ per ball.

GRAPTING THREAD.-Waxed, at $15 \mathrm{c}$ per ball.

If by mail, add 2c per ball for unwaxed and $7 \mathrm{c}$ per ball for waxed.

GRAFTING KNIVIS.-Hand forged razor steel, $40 \mathrm{c}$ each; $45 \mathrm{c}$ by mail.

BUDDING KNIVES.-Ebony handle, bone tip for raising bark, finest razor steel, 75c each; add 5c for postage.

PRUNING SHEARS.-Best made; $\$ 1.25$ each; $\$ 1.35$ by mail.

BFES, QUEFNS, HONEY, BEFKEPER' SUPPIIES-Best goods; write for prices. 


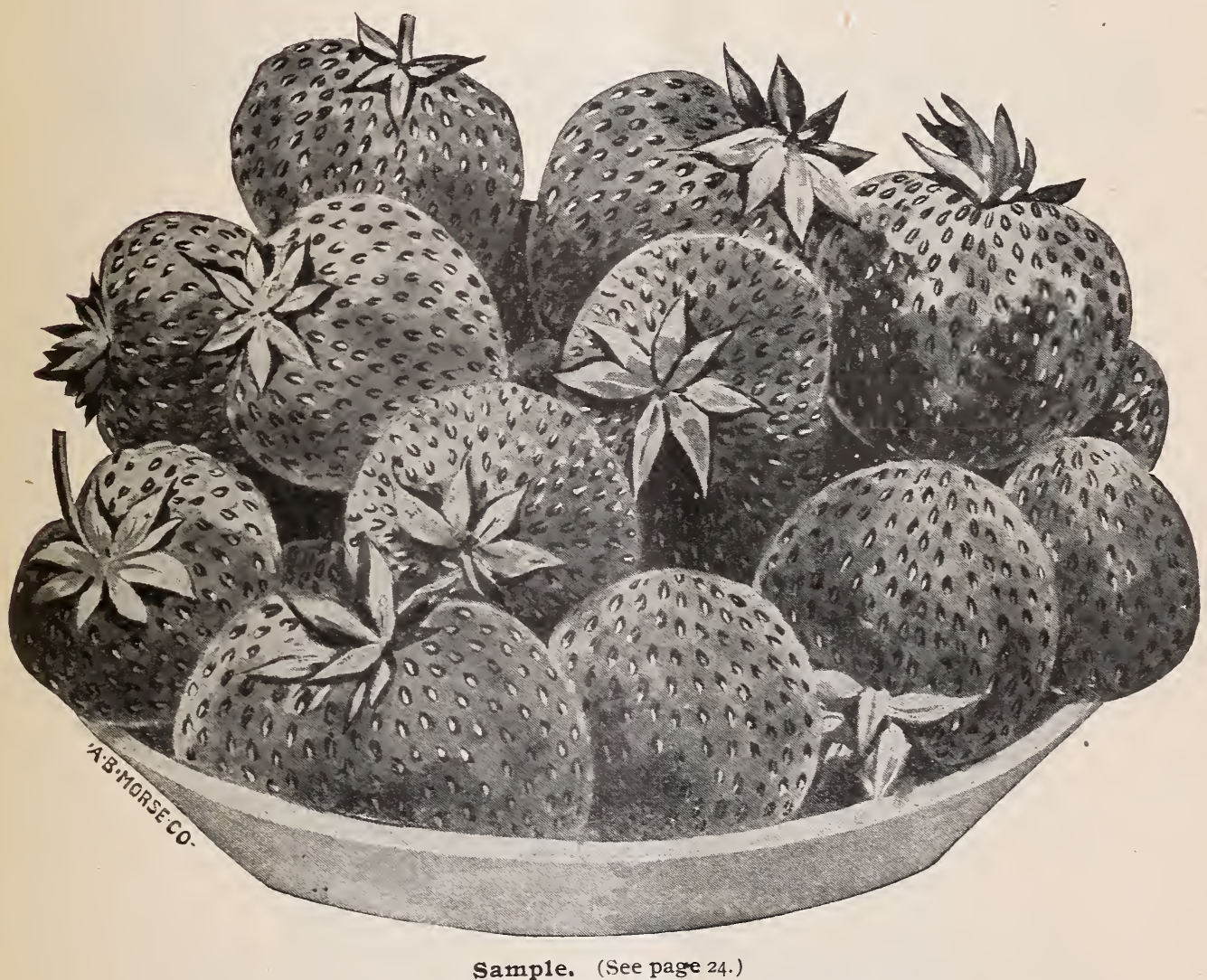




\section{INSECTICIDES FOR BITING INSECTS.}

\section{ARSENITES, PARIS GREEN.}

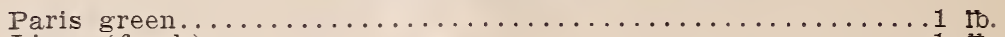

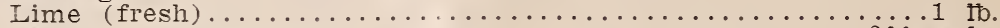

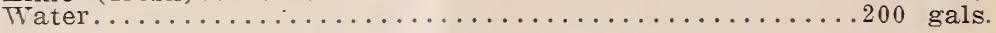

IEAD ARSENATE.

Lead Acetate (sugar of lead) .................

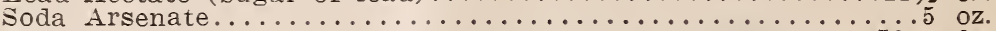

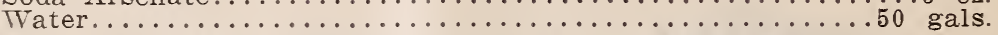

Pulverize and dissolve the acetate and arsenate separately in small quantities of water, add separately to barrel of water and stir thoroughly. This while more expensive than Paris green has the advantage of being more adhesive and less liable to burn foliage. A prepared form of this is sold in the trade under the name "disparene."

\section{ARSENITE OF IIME.}

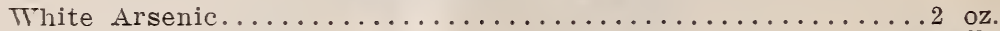

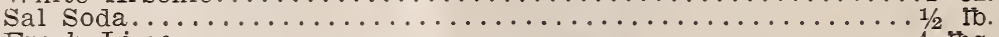

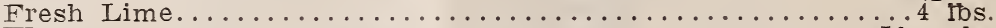

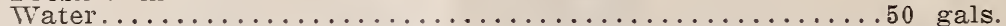

Boil the arsenic and soda together in a small quantity of water till the arsenic is dissolved, slake the lime, strain and add to the barrel of water; then add the soda and arsenic solution and stir for a few minutes.

\section{FOR SUCKING INSECTS-KEROSENE EIMULSION.}

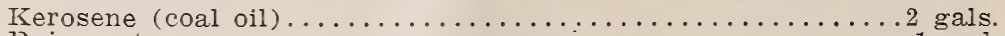

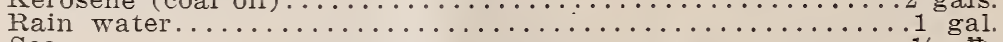

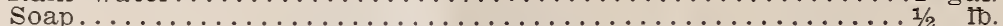

Dissolve soap in water by boiling; take from fire and while hot turn in kerosene and churn briskly for 5 minutes. To be diluted before using with 9 part. water. For scale insects and all sucking insects.

\section{TOBACCO INFUSION.}

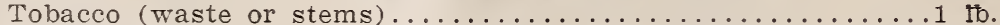

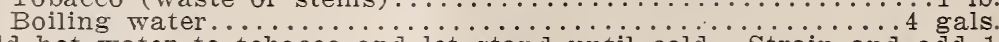

Add hot water to tobacco and let stand until cold. Strain and add 1 ib. of whale oil soap or 2 tbs. of soft soap to each 50 gallons of infusion. For aphis.

\section{HELITBORE.}

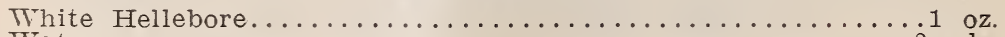

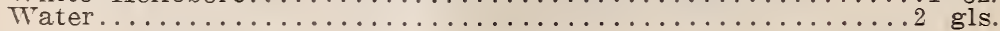

Or to be dusted undiluted on attacked plants.

\section{PYRETHRUM OY INSECT POWDER.}

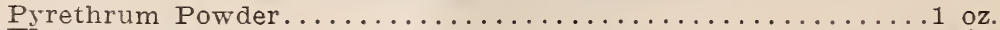

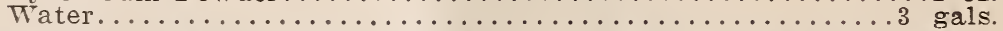

For Dry Application.-Mix thoroughly one part by weight of insect powder With 4 of cheap flour and keep in a close vessel for 24 hours before dusting over plants attacked.

\section{SUIPHUR-IIME-SAIT MIXTURE.}

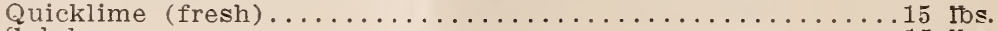

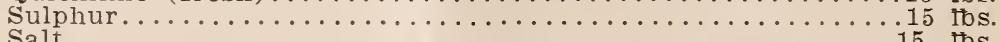

Salt . . . . . .

Place lime in kettle; add sufficient water to slake and stir in sulphur while slaking. Boil until dissolved, an hour or more. Add salt and boil 15 miuntes longer. Add sufficient water to make 50 gallons, and apply while warm.

\section{RESIN-IIME MIXTURE.}

Pulverized resin . . . . . . . . . . . . . . . . . . . . . . .

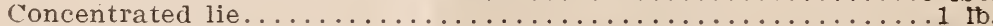

Fish oil, or any cheap animal oil except tallow...........

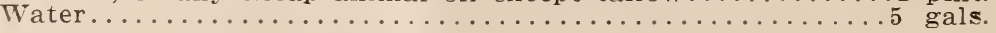


Place oil, resin and a gallon of water in an iron kettle and heat until resin is softened; add lye solution made as for hard soap; stir thoroughly; add remainder of water and boil about two hours, or until the mixture will unite with cold water making a clear amber colored fluid. If the mixture has boilen away ton much, add sufficient boiling water to make 5 gallons.

For use one gallon of this stock solution is diluted with sixteen gallons of water and afterwards three gallons of milk-of-lime or whitewash added. For cabbage and cauliflower add one pound of Paris green to eighty gallons of the above mixture. This of course must not be used after the plants begin to head.

\section{CONBINATION OF FUNGICIDE AND INSECTICIDE.}

When spraying for a fungous disease except when plants are in the dormant state an arsenical mixture may be added to the Bordeaux to advantage and the spraying will be effective against the biting insects as well as plant diseases.

To the Bordeaux add the usual amount of Paris green, lead arsenate or arsenite of lime, letting the Bordeaux answer for the specified amount of water.

\section{DUST SPRAYS.}

Insecticides or fungicides may be used in dust form and applied by a dust spray machine. They should be applied with slaked lime, land plaster or some other perfectly dry powder. Use Paris green and other arsenites at the rate of 1 ib. to 10 Ibs. of the dry powder. Bordeaux may be made in the usual way and water evaporated and residue pulverized and applied dry.

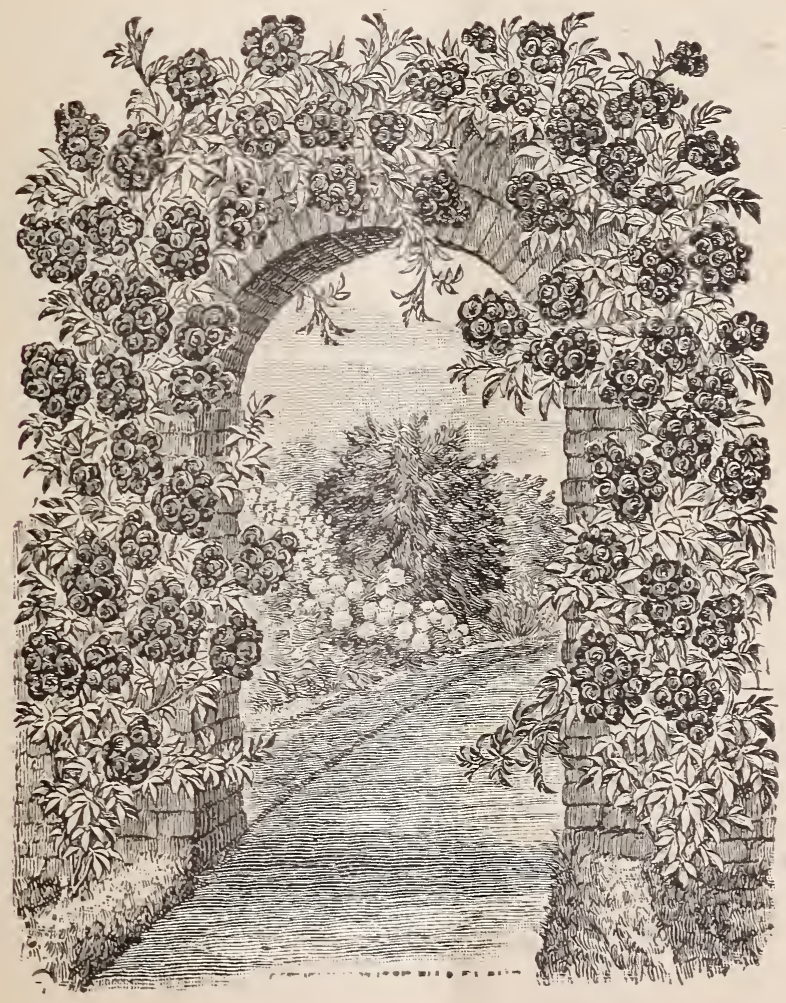




\section{Spraying Calendar.}

\begin{tabular}{|c|c|c|c|c|c|}
\hline PIANT & Insect or Disease & Ist Application & 2nd Application & 3rd Application & 4th Application \\
\hline \multirow{4}{*}{ Apple } & Scab and leaf spot & $\begin{array}{l}\text { Bordeaux before } \\
\text { blossom opens }\end{array}$ & $\begin{array}{l}\text { Just after blossoms } 1 \\
\text { fall }\end{array}$ & 10 to 15 days later & $\begin{array}{c}\text { About two weeks } \\
\text { later }\end{array}$ \\
\hline & $\begin{array}{l}\text { Codling Moth, Car- } \\
\text { culio and Canker } \\
\text { worm }\end{array}$ & $\begin{array}{l}\text { An arsenite just } 1 \\
\text { after b } 10 \mathrm{ss} \text { om } \mathrm{s} \\
\text { fall }\end{array}$ & 10 days later & 10 to 15 days later & $\begin{array}{l}\text { For second brood } \\
\text { spray about July } \\
\text { 1 st }\end{array}$ \\
\hline & San Jose scale & $\begin{array}{l}\text { Sulphur-lime - sa i t } \\
\text { mixture while tree } \\
\text { is dormant }\end{array}$ & \multicolumn{3}{|c|}{$\begin{array}{l}\text { Kerosene emulsion if necessary to keep in check during the } \\
\text { Summer }\end{array}$} \\
\hline & $\begin{array}{l}\text { Oyster-shell scale } \\
\text { Scurfy scale }\end{array}$ & \multicolumn{4}{|c|}{$\begin{array}{l}\text { Kerosene emulsion just after young hatch } \\
\text { Usualty late in May }\end{array}$} \\
\hline Cherry & $\begin{array}{l}\text { Leaf spot and brown } \\
\text { rot }\end{array}$ & $\begin{array}{l}\text { Bordeaux before } \\
\text { buds open }\end{array}$ & $\mid \begin{array}{l}\text { Just after blossoms } \\
\text { fall }\end{array}$ & 10 to 15 days later & $\begin{array}{l}\text { Ammoniacal Copper } \\
\text { Carbonate after } \\
\text { fruit is full grown } \\
\end{array}$ \\
\hline Grape & Mildew and rot & $\begin{array}{l}\text { Bordeaux before } \\
\text { buds start }\end{array}$ & $\begin{array}{l}\text { Bordeaux when } \\
\text { leaves are half } \\
\text { grown }\end{array}$ & When fruit has set & $\begin{array}{l}10 \text { to } 15 \text { days later it } \\
\text { disease persists }\end{array}$ \\
\hline $\begin{array}{c}\text { Peach } \\
\text { Apricot } \\
\text { Nectarine }\end{array}$ & $\begin{array}{l}\text { Leaf curl and brown } \\
\text { rot }\end{array}$ & $\begin{array}{l}\text { Bordeaux before } \\
\text { leaves start }\end{array}$ & $\begin{array}{l}\text { Bordeaux (weak } \\
\text { solution) just af- } \\
\text { ter blossoms } \\
\text { drop }\end{array}$ & $\begin{array}{l}\text { Bordeaux (weak } \\
\text { solution) } 10 \text { to } \\
15 \text { days later }\end{array}$ & $\begin{array}{l}\text { In weak solution use } \\
3 \text { lbs, copper sul- } \\
\text { phate to } 50 \text { gallons } \\
\text { of water }\end{array}$ \\
\hline Pear & $\begin{array}{l}\text { Scab, leaf spot and } \\
\text { leaf blight }\end{array}$ & $\begin{array}{l}\text { Bordeaux before } \\
\text { buds start }\end{array}$ & $\begin{array}{l}\text { Just after blossoms } \mathbf{1} \\
\text { fall }\end{array}$ & 10 to 15 days later & $\begin{array}{l}\text { If foliage is eaten by } \\
\text { insects add Paris } \\
\text { Green to } 2 d \text { and } 3 d \\
\text { spray }\end{array}$ \\
\hline Plum & $\begin{array}{l}\text { Shot bole funges, } \\
\text { brown rot }\end{array}$ & $\begin{array}{l}\text { Bordeaux before } \\
\text { blossoms open }\end{array}$ & $\begin{array}{l}\text { Bordeaux just after } \\
\text { blussoms have } \\
\text { fallen }\end{array}$ & $\begin{array}{l}\text { Bordeaux } 10 \text { to } 15 \\
\text { days later }\end{array}$ & $\begin{array}{l}\text { Ammoniacal copper } \\
\text { carbonate just be- } \\
\text { fore fruit aipens if } \\
\text { rot threatens }\end{array}$ \\
\hline $\begin{array}{c}\text { Currant } \\
\text { and } \\
\text { Gooseberry }\end{array}$ & $\begin{array}{l}\text { "Currant" worm } \\
\text { and Mildew }\end{array}$ & $\begin{array}{l}\text { An arsenical spray } \\
\text { when worms ap- } \\
\text { pear }\end{array}$ & $\begin{array}{l}\text { Hellebore or Pyreth- } \\
\text { rum dusted on af- } \\
\text { ter fruit is formed }\end{array}$ & $\begin{array}{l}\text { For mildew on } \\
\text { berries use Pote } \\
\text { Bordeaux }\end{array}$ & $\begin{array}{l}\text { currants nnd gonse- } \\
\text { tassium Sulphid or }\end{array}$ \\
\hline & Rust & $\begin{array}{l}\text { Bordeaux just after } \\
\text { blossoms fall }\end{array}$ & $\begin{array}{l}\text { Bordeaux } 10 \text { days } \\
\text { later }\end{array}$ & $\begin{array}{l}\text { After picking cut } \\
\text { foliage and burn }\end{array}$ & \\
\hline Strawberry & $\begin{array}{l}\text { Leaf roller and } \\
\text { slugs }\end{array}$ & $\begin{array}{l}\text { Paris Green or other } \\
\text { arsenite as soon } \\
\text { as insects appear } \\
\end{array}$ & $\begin{array}{l}\text { One week to ten } \\
\text { days later if ueces- } \\
\text { sary }\end{array}$ & \\
\hline $\begin{array}{l}\text { Raspberry, Black- } \\
\text { berry andDewberry }\end{array}$ & $\begin{array}{l}\text { Anthracnose and } \\
\text { rust }\end{array}$ & $\begin{array}{c}\text { Bordeaux before } \\
\text { buds burst }\end{array}$ & \begin{tabular}{|c|}
$\begin{array}{c}\text { Bordeaux } 10 \text { to } 15 \\
\text { days later }\end{array}$ \\
\end{tabular} & \multicolumn{2}{|c|}{\begin{tabular}{|c|} 
Bordeaux after old \\
canes are cut out
\end{tabular}} \\
\hline \multirow{3}{*}{$\begin{array}{c}\text { Roses } \\
\text { Ornamentals } \\
\text { and Vines }\end{array}$} & Mildew aud rust & $\begin{array}{c}\text { Bordeaux at first in- } \\
\text { dication of disease }\end{array}$ & $\begin{array}{l}\text { Bordeaux } 10 \text { days } \\
\text { later }\end{array}$ & \multicolumn{2}{|c|}{$\begin{array}{l}\text { Continue to spray with Bordeaux at } \\
\text { intervals of } 10 \text { days as long as dis- } \\
\text { ease persists }\end{array}$} \\
\hline & Slugs & $\begin{array}{l}\text { Hellebore or Pyreth- } \\
\text { rum }\end{array}$ & $\begin{array}{l}\text { Apply at intervals of } \\
\text { one week until de- } \\
\text { stroyed }\end{array}$ & & \\
\hline & $\begin{array}{l}\text { Green Aphis or plant } \\
\text { lice }\end{array}$ & Tobacco infusion & $\begin{array}{l}\text { Apply at intervals of } \\
\text { one week until de- } \\
\text { stroyed }\end{array}$ & \multicolumn{2}{|c|}{$\begin{array}{l}\text { Colonies on small plants best destroy - } \\
\text { ed by dipping }\end{array}$} \\
\hline \multirow{2}{*}{$\begin{array}{l}\text { Melons and } \\
\text { Cucumbers }\end{array}$} & Striped Beetle & $\begin{array}{l}\text { Dust heavily with } \\
\text { slaked lime or ap- } \\
\text { ply Bordeaux mix- } \\
\text { ture }\end{array}$ & $\begin{array}{c}\text { Repeat in } 10 \text { days if } \\
\text { necessary }\end{array}$ & \multicolumn{2}{|c|}{$\begin{array}{l}\text { Decoy crop of very early squash } \\
\text { around field to be sprayed with at } \\
\text { arsenite when beetles appear }\end{array}$} \\
\hline & Blight & $\begin{array}{c}\text { Bordeaux at first } \\
\text { appearance }\end{array}$ & $\begin{array}{l}\text { Repeat at intervals } \\
\text { of } 10 \text { days as long } \\
\text { as necessary } \\
\end{array}$ & \multicolumn{2}{|c|}{$\begin{array}{l}\text { Use Ammoniacal Copper Carbonate af- } \\
\text { ter fruit begins to ripen }\end{array}$} \\
\hline \multirow{4}{*}{ Potato } & "Worms" & $\begin{array}{l}\text { An arsenite in resin } \\
\text { lime mixture at } \\
\text { tirst appeartonce }\end{array}$ & $\begin{array}{l}\text { Repeat every } 10 \text { days } \\
\text { if necessary } \\
\text { But not after head- } \\
\text { ing begins }\end{array}$ & \multicolumn{2}{|c|}{$\begin{array}{l}\text { Pyrethrum if necessary after cabbage } \\
\text { begins to head }\end{array}$} \\
\hline & Scat & \multicolumn{4}{|c|}{$\begin{array}{l}\text { Soak the tubers in corrosive sublimate or formalin solution for an hour and a half } \\
\text { before planting by suspending them in a coarse sack }\end{array}$} \\
\hline & Bligth and rot & $\begin{array}{l}\text { Bordeaux at first in- } \\
\text { dication of blight }\end{array}$ & $\mid \begin{array}{l}\text { At intervals of } 10 \\
\text { rlays as loug as } \\
\text { disease persists }\end{array}$ & \multirow{2}{*}{\multicolumn{2}{|c|}{$\begin{array}{l}\text { Paris Green and Bordeaux may be } \\
\text { comblned and applied at same time }\end{array}$}} \\
\hline & Beetle & $\begin{array}{l}\text { Paris Green or other } \\
\text { arsenite as soon as } \\
\text { they appear }\end{array}$ & $\begin{array}{l}\text { At intervals of } 10 \\
\text { days as long as } \\
\text { they continue }\end{array}$ & & \\
\hline & Blight and rot & $\begin{array}{l}\text { Bordeaux when first } \\
\text { frnit is half grown }\end{array}$ & $\begin{array}{c}\text { Bordeaux } 10 \text { to } 15 \\
\text { days later }\end{array}$ & \multicolumn{2}{|c|}{$\begin{array}{l}\text { Ammouiacal copper Carbonate aner } \\
\text { fruit begins to ripen when necessary }\end{array}$} \\
\hline
\end{tabular}




\section{ORDER SHEET. \\ LINN COUNTY NURSERIES, Center Point, Iowa.}

Forward to

Name of Person

(I adies please sign Miss or Mrs.

Name of Postoffice

Name of Express. Office

Name of County

Name of State.

\section{Amount Enclosed.}

P. 0. Order \$

Draft - \$

Express

Money Order \$

Cash - $\$$.
Total - $\$$

No Order Filed for Less than SI.0o.

SUBSTITUTION-It frequently occurs that special varieties ordered have been in great demand and the stock has been exhausted. In such cases we WILI NOT SUBSTITUTE UNIESS YOU ASK US To, but your money will be returned. If you want us to send the next best, we will. Shall we substitute or not? Yes or No?

Quantity Articles


ORDER SHEET, Continued.

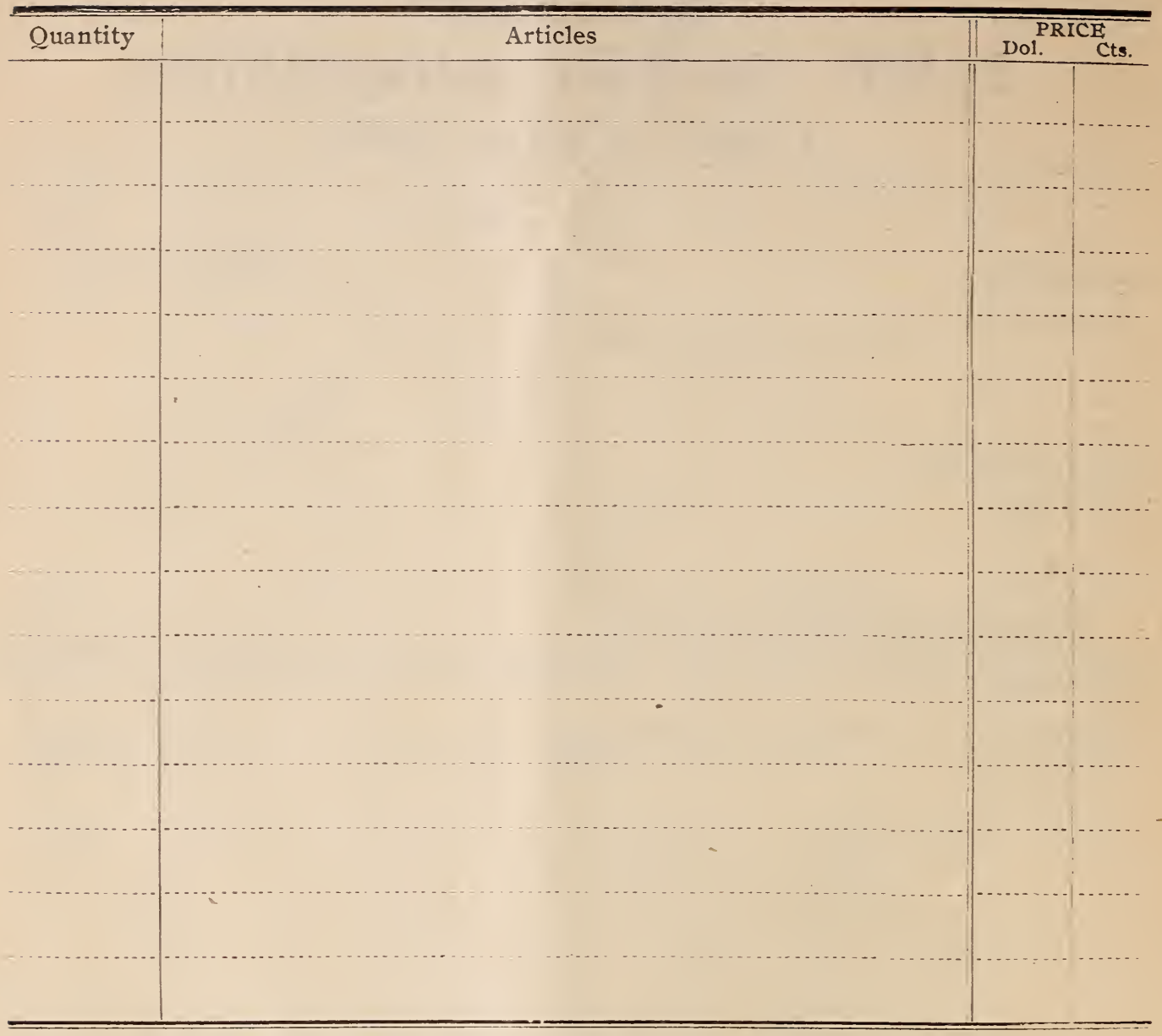

Please give names and address of a few friends who are interested in fruit growing.

NAME

\section{ADDRESS}




\section{Index.}

AsPARAgUS,

APPLES,

"Summer -

. $\quad$ Fall

.6 Winter -

"Crab -

BLACKBERRIES,

Cherries,

Clematis Vines.

Currants,

EVERGREENS, 26-28

Flowering Plants

Gooseberries,

GRAPES,

6-I7

INSECTICIDEs, ETC.,

36

MulberRies,

Ornamental Trees, $28-29$

PEACHES,

PEARS,

Pliums,

9-I4

RASPBERRIES

I 8--2 I

RHUBARB,

Roses,

Shade Trees,

$28-29$

Shrubs, Ornamental

Spray Calenddar

STRAWBERRIES, 
One of our great philanthropists said: "If I knew I were to die to-morrow nevertheless I should plant a tree to-day." If there were more people of a like mind this world would be a much better place to live in.

We are not surprised that some people fail to grow fruit; we have known individuals to take a bill of stock of sufficient size that the proper planting of it would require a long, hard day's work, but they would, as they thought, have it planted all proper and right in the short space of one or two hours. They might about as well have thrown their money in the fire and saved the little work they did do.

\section{To Raise Fruit Means Work Intelligently Applied.}

Never plant trees in an old, hard, uncultivated soddy patch, the trees won't take to it, and very likely you will think hard of the nurseryman who sold them to you, instead of kjrking yourself for planting them in such an unfarorable position.

We wish to emphasize this fact, the soil cannot be too well prepared. Plow thoroughly and cultivate frequently.

We advise deep planting for all kinds of fruit trees, in our own orchards we plant one to two feet deeper than the trees stood in nursery. It is our experience that trees planted a sufficient depth are not subject to root injury in such serere winters as 1898 and 1899 .

The number of trees or plants required to plant an acre may be found by dividing the number of square feet $(43,569)$ in an acre by the number of square feet you wish each plant or tree to occupy.

\section{NUMBER OF TREES REQUIRED TO PIANT AN ACRE.}

\begin{tabular}{|c|c|c|c|c|}
\hline $25 \mathrm{ft}$. & ", & , & , & $\ldots \ldots \ldots \ldots$ \\
\hline $0 \mathrm{ft}$. & ", & , & ", & $\ldots \ldots \ldots \ldots 110$ \\
\hline ft. & $"$ & ", & $"$ & $\ldots \ldots \ldots \ldots 13$ \\
\hline ft. & ", & ", & " & $\ldots \ldots \ldots \ldots 20$ \\
\hline ft. &, & , & $"$ & $\ldots \ldots \ldots 300$ \\
\hline ft. & , & , & $"$ & $\ldots \ldots \ldots \ldots 43$ \\
\hline $\mathrm{ft}$. &.$"$ & , & , & $\ldots 680$ \\
\hline ft. & , & ", & , & $\ldots 1,210$ \\
\hline $\mathrm{ft}$. & $"$ & ", & ", & $\ldots 1,745$ \\
\hline ft. & , & " & " & $\ldots 2,72$ \\
\hline $\mathrm{ft}$. & ", & ", & ", & $\ldots \ldots \ldots{ }_{4,8}$ \\
\hline
\end{tabular}

$8 \times 12$ ft. apart............ 450

$12 \times 16 \mathrm{ft} . \quad, \quad \ldots \ldots \ldots \ldots \ldots \ldots \ldots 225$

$16 \times 20 \mathrm{ft} . \quad " \quad \ldots \ldots \ldots \ldots \ldots \ldots 113$

$20 \times 24 \mathrm{ft}$.

Strawberry for garden per sq. rod.

$2 \mathrm{x} 2 \mathrm{ft}$ apart.............. 75

$1 \times 2 \mathrm{ft} . \quad " \quad \ldots \ldots \ldots \ldots \ldots \ldots \ldots 125$

$1 \mathrm{x} 1 \mathrm{ft} . \quad, \quad \ldots \ldots \ldots \ldots \ldots \ldots \ldots 270$

$1 \frac{1 / 2}{2} 31 / 2$ ft. per acre......... $\$, 300$

Blackberry plants.

$31 / 2 \times 7$ ft. per acre.............. 1,800

Raspberry in hedge row.

x $\delta$ ft. apart...................

$1 \mathrm{x} 12$ ft. per acre..............

If you cannot well avoid planting your trees in an old soddy, uncultivated orchard site, the following plan will be a success if followed out carefully, viz.: Dig the holes in the fall and dig them twice as large as would be necessary under ordinary circumstances; let them stand open over winter to catch and retain as much moisture as possible; also the action of the frost, the process of frequent thawing and freezing, will be a great aid in preparing the soil for tree growth. Immediately after you have planted your trees, before the soil loses any of its moisture, thoroughly mulch a space of at least a square rod of which the tree occupies the center. We know of no other plan by which you can make a success of planting trees in an old soddy uncultivated orchard.

\section{Local Agents Wanted in Every County in the State.}

Write for our terms to agents. or special terms in club orders.

Always be sure to address:

THE LINN COUNTY NURSERY, CENTER, POINT, IA. S. W. Snyder, Proprietor. 